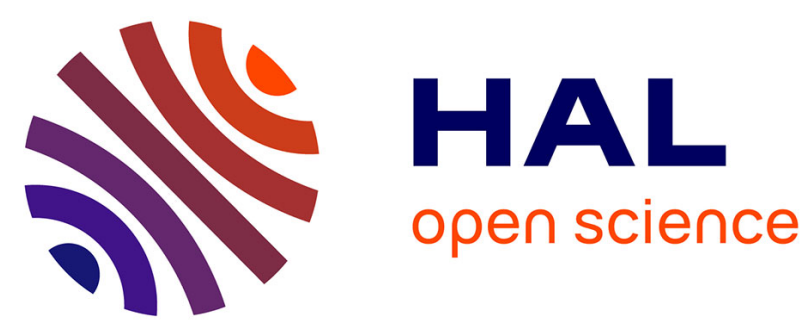

\title{
Spatio-temporal evolution of the Choisille River (southern Parisian Basin, France) during the Weichselian and the Holocene as a record of climate trend and human activity in north-western Europe
}

Eymeric Morin, Jean-Jacques Macaire, Florent Hinschberger, Isabelle

Gay-Ovejero, Stéphane Rodrigues, Jean-Paul Bakyono, Lionel Visset

\section{To cite this version:}

Eymeric Morin, Jean-Jacques Macaire, Florent Hinschberger, Isabelle Gay-Ovejero, Stéphane Rodrigues, et al.. Spatio-temporal evolution of the Choisille River (southern Parisian Basin, France) during the Weichselian and the Holocene as a record of climate trend and human activity in north-western Europe. Quaternary Science Reviews, 2011, 30 (3-4), pp.347-363. 10.1016/j.quascirev.2010.11.015 . insu-00547675

\section{HAL Id: insu-00547675}

https://hal-insu.archives-ouvertes.fr/insu-00547675

Submitted on 20 Jan 2011

HAL is a multi-disciplinary open access archive for the deposit and dissemination of scientific research documents, whether they are published or not. The documents may come from teaching and research institutions in France or abroad, or from public or private research centers.
L'archive ouverte pluridisciplinaire HAL, est destinée au dépôt et à la diffusion de documents scientifiques de niveau recherche, publiés ou non, émanant des établissements d'enseignement et de recherche français ou étrangers, des laboratoires publics ou privés. 


\title{
Spatio-temporal evolution of the Choisille River (southern Parisian Basin, France) during the Weichselian and the Holocene as a record of climate trend and human activity in north-western Europe
}

\author{
Eymeric Morin ${ }^{\mathbf{a}}$, Jean-Jacques Macaire ${ }^{\underline{a}}$, Florent Hinschberger ${ }^{\mathbf{a}}$, Isabelle Gay-Ovéjéro ${ }^{\underline{a}}$, \\ Stéphane Rodrigues ${ }^{\underline{a}}$, Jean-Paul Bakyono ${ }^{-}$and Lionel Visset ${ }^{\underline{b}}$
}

${ }^{a}$ Université François-Rabelais de Tours, CNRS/INSU, Université d'Orléans, UMR 6113 ISTO (Institut des Sciences de la Terre d'Orléans), Laboratoire de géologie, Avenue Monge, F-37200 Tours, France

${ }^{\mathrm{b}}$ Université de Nantes, UMR CNRS 6566, Laboratoire d'écologie et des paléoenvironnements atlantiques, Faculté des Sciences et des Techniques, 44322 Nantes, France

\begin{abstract}
The morpho-sedimentary evolution of the Choisille floodplain (lowland river, catchment: $288 \mathrm{~km}^{2}$ ), a tributary of the River Loire in the south-western Parisian Basin, was studied through 61 core drillings along eight transects and a geophysical survey located in four stretches of the river: stretches A and B correspond to two sub-catchments, and stretches C and $\mathrm{D}$ are in the main valley. Sixty ${ }^{14} \mathrm{C}$ and four OSL datings were obtained, and sediments were analysed on seven reference cores. Eight phases of evolution differing markedly from the evolution of more northern areas in the Parisian Basin and north-western Europe were identified from spatio-temporal distribution of nine lithological facies. The deepest incision phase (1) occurred during the first part of the Weichselian, followed by the deposition of a gravelly-sandy unit (phase 2) during the Middle Pleniglacial, which was deeply incised (phase 3 ), probably during the Bölling. From the Allerød up to the last third of the Boreal (phase 4), sedimentation was continuously dominated by peaty deposits, with no evidence of either increased hydraulic energy during the Younger Dryas, or of incision during the LateGlacialHolocene transition. This trend seems to reflect the specificity of the south-western Parisian Basin climate from the Late Weichselian up to the end of the Boreal, due to the influence of the Atlantic Ocean, compared to more northern areas where the climate was more continental. The downstream incision trend during the last third of the Boreal up to the Subatlantic (phases 5 and 6) indicates a sharp increase in precipitation and vegetation cover; the lack of peaty sediments, widespread in north-western Europe, and also of precipitated carbonates frequent in the Parisian Basin, seems to be due to local physiographic characteristics. The main part of the sediment filling, which is principally silty and retrograde, began during the Subatlantic (phase 7 and 8) as a result of deforestation of the plateaux for crop farming. High humaninduced sediment yield and storage concealed the possible impacts of climate change on fluvial dynamics: lithological facies change from phase 7 to 8 can only indicate the autogenic morphological evolution of the floodplain in accretion. The non-univocal upstreamdownstream variation in the start of phase 7 shows that sediment yield varied in space and time in the catchment, particularly in relation to the agricultural potential of the different areas; this observation could be used to testify human-induced sedimentation in other catchments.
\end{abstract}

\section{Introduction}


Fluvial archives have often been used to reconstruct palaeoenvironments, especially in lowlands where there are few lacustrine archives (e.g. [Macklin and Needham, 1992], [Bohncke, 1993], [Limondin-Lozouet et al., 2002] and [Visset et al., 2005]). They can be used to study the palaeohydrological and morpho-sedimentary evolution of rivers in relation to palaeoenvironmental changes, for example during the LateGlacial (e.g., [Haesaerts, 1984], [Vandenberghe et al., 1994], [Rose, 1995], [Antoine, 1997], [Antoine et al., 2003], [Pastre et al., 2002a] and [Pastre et al., 2003]). They also demonstrate the extensive development of silty sedimentation and hydro-sedimentary disturbances due to human activities during the last millenia (e.g. [Taylor and Lewin, 1996], [Brown, 1997], [Macklin, 1999], [Pastre et al., 2002a] and [Macaire et al., 2006]). In the Parisian Basin, studies dealing with river evolution since the Upper Pleniglacial mainly concern the middle or northern parts of the basin ([Antoine, 1997], [Pastre et al., 1997], [Pastre et al., 2002b], [Orth et al., 2004] and [Lespez et al., 2005]). There are a few similar studies of southern Parisian Basin rivers dealing mainly with palaeoenvironments through palynological analysis ([Cyprien et al., 2004], [Visset et al., 2005] and [Visset et al., 2008]). Few studies concern the evolution of the Middle Loire ([Macaire, 1981], [Garcin et al., 1999], [Carcaud et al., 2002] and [Castanet, 2008]) or its tributaries ([Visset et al., 1999], [Carcaud et al., 2000] and [Macaire et al., 2006]). Geological and palaeopedological studies of the Pleistocene sediments in the south-western Parisian Basin showed that the palaeoclimates differed noticeably from those of more northern regions ([Macaire, 1981], [Macaire, 1986a] and [Macaire, 1986b]). Two main questions arise: (1) are the hydrological and sedimentary changes in the southern Parisian Basin rivers since the Weichselian similar to those of north-western European rivers? (2) Is there a trend in the climatic and anthropogenic forcing factors in this region?

The study of fluvial archives is often based on analysis of one or several core drillings in palaeochannels ([Visset et al., 1999] and [Carcaud et al., 2000]) which are favourable environments to the deposition and preservation of organic-matter (OM) rich sediments, with different palaeoenvironmental proxies and sufficient OM for datings using the radiocarbon method (e.g. Brown and Keough, 1992). Nevertheless, the information about fluvial dynamics given by palaeochannels is poor. Floodplains, which are more extended deposition sites, contain sediments which are more representative of the hydro-sedimentary processes of rivers (Walling et al., 1996), although they contain less palaeoenvironmental proxies and few OM for datings. Due to the diversity of the morpho-sedimentary sites ([Reineck and Singh, 1980] and [Bridge, 2003]) and the variability of the time record (Macaire, 1990) in fluvial systems, information must be obtained throughout the floodplain by studying full transversal transects. Such surveys have been carried out on several rivers in north-western Europe, mostly on small rivers, easier to study (e.g. [Vandenberghe et al., 1987], [Antoine, 1997], [Pastre et al., 1997] and [Macaire et al., 2006]) than on large ones with a more complex set of boundary conditions as lithology of substratum, climate and topography (i.e. [Garcin et al., 1999], [Castanet, 2008] and [Erkens et al., 2009]). Studies which analyse and compare upstream to downstream transects across the whole fluvial system are rarer ([Rose, 1995], [Macklin, 1999], [Houben, 2003], [Orth et al., 2004], [Lespez et al., 2005] and [de Moor et al., 2008]).

The aim of this article is to analyse the spatio-temporal evolution of the floodplain of a small river, the Choisille, from upstream to downstream, in order to understand the representativeness of the observations made in each stretch, and to analyse the characteristics of the palaeoclimate and human activities from their impacts on the fluvial morphosedimentary evolution, including comparison of sub-catchments differing in lithology. These observations will be interpreted considering vegetation evolution in this region ([Cyprien et al., 2004], [Visset et al., 2005] and [Visset et al., 2008]). A further aim is to investigate the 
relationship between this small river and the River Loire which is the main stem. Comparing our results with other work on more northern Parisian Basin rivers on the one hand and northwestern European rivers on the other will highlight the specificity of the area under study.

\section{The catchment of the Choisille River}

Based on Starkel's (1991) classification, the Choisille is a lowland river. It is a tributary of the River Loire (catchment areas: $288 \mathrm{~km}^{2}$ and $117,000 \mathrm{~km}^{2}$ respectively), the confluence located at $47^{\circ} 23^{\prime} 35^{\prime \prime}$ latitude north and $0^{\circ} 38^{\prime} 51^{\prime \prime}$ longitude east, near the town of Tours in the southwestern Parisian basin (Fig. 1a). The Choisille catchment comprises plateaux decreasing in elevation from north $(182 \mathrm{~m})$ to south (about $100 \mathrm{~m}$ ), incised by a dense hydrographical network (minimum floodplain elevation: $48 \mathrm{~m}$ ). The catchment bedrock is composed of Mesozoic and Cenozoic sedimentary beds slightly tilted towards the south-west in the northern part of the catchment, and forming a synclinal depression on an NNE-SSW axis, which is also the main direction of the principle valley ("Grande Choisille" river), in the southern part (Rasplus and Alcaydé, 1974). Upper Turonian and Senonian chalks outcrop in the valley slopes in the northern and southern stretches (Fig. 1b). These formations are covered with Senonian and Eocene sand, clay, clay with flint and conglomerate forming the main bedrock of the plateaux and outcropping mainly in the northern half of the catchment. Upper Eocene lacustrine limestones and marls form extensive outcrops on the plateau in the southern half of the catchment. All these formations are covered with thin, sparsely scattered beds of Miocene and Pliocene clayey sands and gravels, and more extensive thin Quaternary sandy lœss $(<1 \mathrm{~m})$. Soils are varied: calcimagnesic, brown, leached or hydromorphic.

The "Choisille" is a network of perennial rivers comprising the "Grande Choisille" (stretches $\mathrm{C}$ and D) which has many tributaries such as the "Choisille of Chenusson" (stretch A) and the "Choisille of Saint-Roch" (stretch B) which we studied in particular (Fig. 1b). The mean longitudinal gradients of these three rivers are 3,9 and 5\%o respectively, and the mean annual water discharge of the Grande Choisille at Mettray is about $0.85 \mathrm{~m}^{3} \mathrm{~s}^{-1}$ (banque Hydro, MEDD/DEC; years 1971-1984). These rivers are fed by rainfall and springs in lacustrine limestone. The present climate in the region is temperate with oceanic features: the average annual rainfall and temperature vary from 706 to $672 \mathrm{~mm}$ and $11.1-11.5^{\circ} \mathrm{C}$ in the northern and southern parts of the catchment respectively. Three main areas can currently be distinguished: (i) the northern half of the catchment where forests and pasture dominate, (ii) the Mettray plateau in the southern half where crop farming dominates with some woods and urban areas, and (iii) the valleys, which are woodland, marsh or pastureland upstream and extensively urbanized downstream. Human settlement is testified since the Lower Palaeolithic by numerous archaeological sites scattered over the catchment, mainly located in the valleys before Bronze Ages, and also on the plateaux after this period (unpublished reports). Identified archaeological sites are more abundant in the southern part of the catchment, and scarce and more recent in the northern part.

\section{Materials and methods}

Facies and thickness of the floodplain sediments were observed directly from 61 core drillings, all retrieved with a percussion sampler $\left(\right.$ Eijkelkamp $^{\circledR}$ ) along 7 transects in four stretches (Fig. 1b). Two stretches are located in sub-catchments: A on the "Choisille of Chenusson" (2 transects: NAU and HAR), and B on the "Choisille of Saint-Roch" (2 transects: ROC and 
BIL), with bedrocks mainly composed of siliceous and carbonated rocks respectively. Two others stretches named C (1 transect: POI) and D (2 transects: BJE and CHA; one isolated core drilling in an abandoned channel: RIA) are located in the middle and downstream parts of the Grande Choisille floodplain respectively. One more transect (BRO), studied by Cyprien-Chouin et al. (2004) and located in stretch C, is also discussed below. Along transects, the distance between the cores ranges from 5 to $20 \mathrm{~m}$. With the exception of stretch $\mathrm{D}$ and transect BRO (stretch $\mathrm{C}$ ), the elevation at each drilling point was measured with an accuracy of $2 \mathrm{~cm}$ by topographical survey using an electronic total station and data logger (Trimble $\mathrm{M} 3{ }^{\circledR}$ ). Sediment-infilling geometry was studied in stretches A and D using a Slingram prospecting method (McNeil, 1980). An EM31 conductivity meter (Geonics Ltd. ${ }^{\circledR}$, $3.66 \mathrm{~m}$ between emitter and receiver, vertical dipoles) was used to measure the electrical conductivity of the ground in milli-Siemens per meter. This instrument has a depth of investigation of about $6 \mathrm{~m}$ (more sensitive between 0.5 and $3 \mathrm{~m}$ ). About $27 \mathrm{~km}$ of electromagnetic profiles were performed within the Choisille floodplain, representing 4500 measurement points and covering about $2 \mathrm{~km}$ of the floodplain in stretches A and D.

Sixty ${ }^{14} \mathrm{C}$ dates were obtained from the Laboratory of Isotope Geochemistry, University of Arizona, Tucson (USA) and the Beta Analytic Inc. Laboratory, Miami (USA) on peat, wood, organic sediment and charred material using conventional or AMS (Accelerated Mass Spectrometry) methods. ${ }^{14} \mathrm{C}$ dates were calibrated using CALIB (version 6.0; Stuiver and Reimer, 1993) and the IntCal09 calibration dataset (Reimer et al., 2009). The cal. ages are reported with the extremes of $2 \sigma$ ranges. Four OSL dates were obtained on gravelly-sandy sediments from the Geological Institute of Hungary, Budapest. Equivalent doses were measured using the single-aliquot regenerative-dose protocol (Murray and Wintle, 2000) on quartz grains $(160-200 \mu \mathrm{m})$ from the following depth intervals: $365-375$ and 392-402 $\mathrm{cm}$ on core POI1 (stretch C), and 415-425 and 475-485 cm on core CHAr (stretch D).

Sedimentological analyses were performed on one reference core per transect in stretches A, B and D (NAUr, HARr, ROCr, BILr, CHAr, BJEr) and on core RIA. Sediment samples were collected by slice increments of 5-20 cm in the cores depending on lithological limits. OM, carbonate and silicate and oxi-hydroxide contents were determined on the $<2 \mathrm{~mm}$ fraction for each sample (as mass \% of the bulk). OM content was estimated by multiplying by two the content in total organic carbon (Duchaufour, 1983) determined by Rock-Eval pyrolysis. Carbonates, which are terrigenous and/or bioclastic, were quantified by calculating the difference between the weight of the bulk (50-200g according to the sample) and the weight of the residue after dissolution of the carbonates with $\mathrm{HCl} \mathrm{N} / 2$ and wash with demineralized water. Silicate and oxi-hydroxide content was calculated as the difference between $100 \%$ and the OM and carbonate contents. After eliminating organic fragments, carbonates, and small concretions of precipitated Fe oxides using Jeanroy's (1983) method, the sediment-grain size was analysed by wet-sieving for the gravel and sand, and by laser microanalyses (Cilas $920^{\circledR}$ ) for the silt and clay. The gravel $(>2 \mathrm{~mm})$, sand $(50 \mu \mathrm{m}-2 \mathrm{~mm})$, silt $(2-50 \mu \mathrm{m})$ and clay $(<2 \mu \mathrm{m})$ fractions were quantified. The quantity of gravel-rich sediment sampled by core drilling being low (400 g maximum), the content in gravel determined by sieving was not very significant. The mineralogical composition of the clay fraction $(<2 \mu \mathrm{m})$ was determined by XRD (Rigaku diffractometer, anticathode $\mathrm{Cu}$ ). Semi-quantitative data were obtained by estimating the surface area of the (001) diffraction peaks of the clay minerals on diffractograms. The percentages of the sediment components (mainly OM and dominant classes of grain size) used to define the lithological facies were chosen to extend the field observations made on the reference cores to the other cores on which no sedimentological analyses were performed. 


\section{Results}

\subsection{Facies composition and distribution}

The lithological facies and their distribution in the transects are shown in Fig. 2. The composition of reference cores sediments is shown in Fig. 3. Nine lithological facies were identified: six fluvial facies [gravel and sand (GSa), peaty silt (PSi), silty peat (SiP), clayeysandy silt (CSaSi), organic-matter poor clayey silt (oCSi) and organic-matter rich clayey silt (OCSi)], debris flow (DF), slope deposits (SD), and anthropogenic embankment (AE).

The GSa facies was observed at the lowest part of the alluvial infilling in all transects, but also formed rare beds in CSaSi (transects BIL and ROC) and oCSi (transect BJE). In GSa, the heterometric gravel $(\mathrm{G})$ and sand $(\mathrm{Sa})$ fractions form more that $50 \%$ of the sediment bulk, with at least $5 \%$ gravel. The contents of clay $(\mathrm{C})+$ silt $(\mathrm{Si})$ fractions vary greatly from one bed to another - from $2 \%$ to $70 \%$ of the $\mathrm{C}+\mathrm{Si}+\mathrm{Sa}$ fractions (the $\mathrm{G}$ fraction is excluded as its contents are not significant). Sand rich facies can exhibit laminae or beds. The sandy fraction is mainly composed of quartz grains, sometimes of glauconite, and can contain up to $22 \%$ of detrital carbonate grains, especially in stretches A and D (transects HAR and BJE). The gravel fraction is composed of fragments up to $5 \mathrm{~cm}$ long, which are mainly siliceous (predominantly Cretaceous silex, with Cretaceous bioclasts and Eocene silcretes), and occasionally calcareous (Cretaceous and Eocene). The $<2 \mu \mathrm{m}$ fraction is generally composed of smectites, which often dominate, kaolinite, illite group minerals (illite, muscovite and/or glauconite), and quartz which is more abundant in silt and clay-rich grain-size samples. The GSa-facies thickness can be up to $3.2 \mathrm{~m}$ in stretch $\mathrm{D}$, and its irregular surface (up to $2.9 \mathrm{~m}$ change in altitude) is more marked in stretch D and the downstream part of B (transect BIL).

The brownish to blackish PSi and SiP peaty facies form small beds (rarely laminated) which are usually thin (a few $\mathrm{dm}$ ) but can be up to $1.5 \mathrm{~m}$ thick (transect POI). They are located in the depressions at the top of GSa which they directly cover (transects ROC, BIL, CHA, BJE). They can also form more extended beds between the silty facies (transects POI and BRO) or a large part of a palaeochannel infilling (core RIA, Fig. 3). The OM contents are higher than $45 \%$ or between 15 and $45 \%$ in the $\mathrm{SiP}$ and PSi respectively. The OM is composed of more or less decomposed plant debris (Phragmite or Carex limbs, wood fragments, fruits). The mineral fraction is mainly silty and quartzeous, and the carbonates which are sometimes abundant (up to $30 \%$ at BIL) correspond to mollusc shells. The composition of the $<2 \mu \mathrm{m}$ fraction is similar to that of GSa, but the smectite contents often decrease in favour of quartz and kaolinite which can dominate (transect CHA). PSi is more frequent than SiP which it usually flanks. These facies were observed in the four stretches under study.

The CSaSi facies, mainly composed of silt with a little clay (2-15\%), contains less than $15 \%$ $\mathrm{OM}$ and $5 \%$ gravel, and more than $10 \%$ sand (mainly fine: $50 \mu \mathrm{m}-200 \mu \mathrm{m}$ ). The coarser grains are siliceous, and in stretch D they can be bioclasts (particularly cretaceous bryozoans). The carbonate content (often $<3 \%$ ) can be higher than in the other facies: $9 \%, 7 \%$ and $43 \%$ in stretches A, B and D respectively. These carbonates are mollusc shells, millimetric concretions more abundant in mollusc-rich beds, and detrital grains. The composition of the $<2 \mu \mathrm{m}$ fraction varies greatly across samples, especially in stretches A and B: smectites can dominate or be similar in quantity to kaolinite, the illite group is not very abundant, while quartz is sometimes very abundant. Lepidocrocite was identified in the beds located just above GSa. CSaSi usually covers the above-mentioned facies (GSa, PSi or SiP) and constitutes the major part of the floodplain infilling in stretches $\mathrm{A}$ and $\mathrm{B}$, where it can be 
thicker than $3 \mathrm{~m}$. It is present, but less developed in stretches $\mathrm{C}$ and $\mathrm{D}$ where it forms greyishblue beds which are thin, not extensive, and overlain by the silty facies described below.

The oCSi and OCSi facies are composed of a dominant silt fraction (up to 90\%), the clayey and sandy fractions being little abundant ( $5-15 \%$ and $<10 \%$ respectively). These facies differ in their OM contents: OM-poor clayey silt (oCSi) and OM-rich clayey silt (OCSi), containing less than 5\% and 5-15\% OM respectively. The OM is usually dispersed in the bulk, but it can also consist of plant fibres, often arranged vertically in the sediments. oCSi is brown to beige in oxic conditions (at a depth of between 0 and $0.5 \mathrm{~m}$ ), enriched in ochred stains and ferrugineous concretions at depths of between about 0.5 and $1 \mathrm{~m}$, becoming bluish-grey below in anoxic conditions. OCSi is brownish to darkish. The silt is mainly quartzeous, and the carbonates form up to $22 \%$ of the bulk (mollusc shells and/or concretions). There are no detrital carbonates. The minerals forming the $<2 \mu \mathrm{m}$ fraction, whose quantity varies little from one sample to another, are similar to those of the above-mentioned facies. oCSi is the most frequent facies: it is interbedded in $\mathrm{CSaSi}$ in stretches $\mathrm{A}$ and $\mathrm{B}$ and greatly dominates in stretches $\mathrm{C}$ and $\mathrm{D}$ where it can be up to $3 \mathrm{~m}$ thick and constitutes the major part of the floodplain infilling. OCSi is less frequent and appears at different levels in oCSi, mainly in stretches $\mathrm{C}$ and $\mathrm{D}$. At the top of the sediment pile, it corresponds to the present soil.

Deposits with an abundant ( $>50 \%$ of the bulk) clayey-silty, sometimes a little sandy, brownish to greyish matrix, containing angular and broken gravel with pebbles, were interpreted as slope deposits (SD). This was confirmed by the monogenic composition of the coarse elements and the location of the facies at the floodplain borders. Debris flow deposits (DF) occurs in stretches A and B and its composition is similar to that of SD, apart from the gravel and pebbles which are polygenic, and the matrix which is richer in sand. Both SD and $\mathrm{DF}$ are interbedded in fluvial deposits. Core drillings also cut through anthropogenic embankments (AE) characterized by their heterogeneity and the presence of bricks, tiles, slates, slag, etc.

\subsection{Datings}

GSa was dated by OSL at $11,910 \pm 1030$ and $7860 \pm 650$ yrs on depth intervals of $392-$ $402 \mathrm{~cm}$ and $365-375 \mathrm{~cm}$ respectively in core POI1 (stretch C), and at 44,550 \pm 4580 and $6670 \pm 540 \mathrm{yrs}$ on depth intervals of $475-485 \mathrm{~cm}$ and $415-425 \mathrm{~cm}$ respectively in core CHAr (stretch D) (Fig. 2). ${ }^{14} \mathrm{C}$ datings and cal. ages are shown in Table 1. In the discussion, they are expressed in cal. years BP and are related to the LateGlacial and Holocene chronozones using the boundaries defined by Visset et al. (2005) for mid-west France (a comparison with the chronology of Mangerud et al. (1974) is given in [Fig. 5] and [Fig. 6]). Of the 60 dates, 5 are located in the LateGlacial, 8 in the Preboreal and the Boreal, 5 in the Atlantic, 1 in the Subboreal and 41 in the Subatlantic. The Atlantic and the Subboreal were only identified in stretches C and D, while in stretches A and B, almost all the dates are in the Subatlantic.

\subsection{Geophysical dataset}

Conductivity depends closely on the grain size and porosity of the sediment, making electromagnetic prospecting highly suitable for distinguishing coarse deposits (sand and gravel), generally characterized by low conductivity values, from finer ones (silt, clay and peat) (Archie, 1942; [Gourry et al., 2003] and [Froese et al., 2005]). Thus, in the case of resistive bedrock, such as chalk or limestone in the Choisille catchment, low conductivities are usually associated with coarse deposits or thin sedimentary filling, whereas high 
conductivities indicate a thick layer of fine deposits (Hinschberger et al., 2006). In both stretches A and D, conductivity ranges from less than $20 \mathrm{mS} / \mathrm{m}$ at the edges of the valley where alluvial sediments are thin $(<0.5 \mathrm{~m})$ to more than $50 \mathrm{mS} / \mathrm{m}$ in the central parts where the fine deposits reach their maximum thickness (Fig. 4). The high resistivity values in the eastern part of stretch D correspond to the Palluau alluvial terrace formed of gravelly sand ([Fig. 1] and [Fig. 4]). Overall, stretch D presents more conductive values than stretch A, although the average sediment thickness is not significantly greater. This may be explained both by the grain size of the fluvial deposits, which are finer in the Grande Choisille floodplain (stretch D), and by the sediment thickness (Fig. 4). In stretch D, the EM31 survey clearly highlights linear conductive structures running parallel to the axis of the valley which are interpreted from core data as palaeochannels filled with fine deposits: a single channel is observed at RIA and two channels at the north of Charcenay. In stretch A, there is no clearly identified palaeochannel. In some areas the floodplain signal disappears: at the outlet of La Morinière, a dry and colluvial side-valley (Fig. 4), the conductivity is $<20 \mathrm{mS} / \mathrm{m}$ a few meters downstream from the confluence, whereas there are higher conductivity values upstream and downstream. This observation can also be made downstream of the dry side-valley called Bois Mortier (Fig. 4) near the HAR transect, with a higher range of conductivity values. In stretch A, geophysics shows the influence of slope processes in the narrow floodplain through the deposition of non-fluvial bodies from the dry side-valleys which have formed dams just downstream of their confluences.

\section{Discussion}

\subsection{Main phases of the floodplain evolution in each stretch}

Eight phases of fluvial dynamics, numbered 1 to 8 from the oldest to the most recent, were identified in each stretch from the distribution of lithological facies and datings ([Fig. 5] and [Fig. 6]). They correspond either to a sediment-unit deposition phase, numbered according to the phase concerned (1SU, 2SU, etc.), and/or to an incision phase (1I, 2I, etc.). SU units are composed of one or several of the 9 defined facies.

In stretch D, located downstream of the Grande Choisille, the CHA and BJE transects and RIA core data present a few differences. The first floodplain evolution phase is marked by the chalky bedrock incision (phase 1I), after the Palluau terrace deposition ([Fig. 1] and [Fig. 4]) and before a phase (2SU) of coarse sediment deposition (GSa facies) dated 44,550 $\pm 4580 \mathrm{yrs}$ (OSL) in the CHAr core (Fig. 6D). The OSL date of $6470 \pm 530$ yrs obtained in the upper part of this unit was eliminated because it is later than the ages of the upper-lying 4SU and 5SU units (four consistent older ${ }^{14} \mathrm{C}$ dates). The very irregular surface of $2 \mathrm{SU}$ indicates a new incision phase (3I) prior to 13779-13418 cal. BP (Allerød): the core drillings and electrical conductivity map ([Fig. 2] and [Fig. 4]) show a main palaeochannel, which is up to $2.3 \mathrm{~m}$ in depth, and sometimes a secondary channel. The following phase (4SU) is characterized by the deposition of sparse, generally OM-rich sediments (mainly SiP, PSi, OCSi, and locally oCSi and CSaSi facies) in the deepest channel, dated between the Allerød and the Boreal (1377913418 cal. BP to 9439-9023 cal. BP). The younger Dryas has not been dated in the sediments. The following phase is marked by more detrital deposits (5SU), composed of the dominant CSaSi facies and also of oCSi and OCSi. 5SU is attributed to the second part of the Boreal up to the end of the Atlantic in regional palynozones (9276-8367 cal. BP to 7713-6319 cal. BP) and extends across the whole valley bottom. The variable altitude (within a range of $1.6 \mathrm{~m}$ ) of the top of 5SU and the absence of sediment from the Subboreal above it indicate a new incision phase (6I). Nevertheless, OM-rich sediments (PSi facies: phase 6SU) dated 5291- 
4875 cal. BP (Subboreal) were stored locally in an abandoned channel (RIA core) during this phase (Fig. 3). Detrital sedimentation (phase 7SU) started again a little before 3630-3376 cal. BP and up to 3200-2373 cal. BP depending on the site, with silty deposits (OCSi and oCSi) throughout the floodplain. Sedimentation has continued up to the present day, becoming less organic (predominant oCSi), except in the present soil (OCSi), since the Early Middle Ages (after 1606-1301 cal. BP): phase 8SU.

The stretch $\mathrm{C}$ (POI and BRO transects) reveals a similar pattern of evolution to that of stretch $\mathrm{D}$ (Figs. $\underline{5} \mathrm{C}$ and $\underline{6} \mathrm{C}$ ). Phases $1 \mathrm{I}$ and $2 \mathrm{SU}$ were identified, and the gravelly-sandy $2 \mathrm{SU}$ provided OSL dates of $11,910 \pm 1030$ and $7860 \pm 650 \mathrm{yrs}$ in core POI1. Incision phase 3I, a little less marked than in stretch $\mathrm{D}$, induced a main channel about $60 \mathrm{~m}$ wide, formed before 13091-12660 cal. BP (end of the Allerød). 4SU was marked by organic sedimentation (SiP, PSi et OCSi) on the bottom or halfway up the palaeochannel from the end of the Allerød (13091-12660 cal. BP) and during the Younger Dryas (12895-12142 cal. BP) and the Preboreal (11226-10784 cal. BP). The Boreal was not dated in that stretch. Sedimentation became more detrital with the deposition of $5 \mathrm{SU}$ (CSaSi, oCSi and OCSi facies) on almost all the valley-bottom surface during the Atlantic (8158-7594 cal. BP and 7412-6987 cal. BP). The very thin sediment pile and the absence of dated materials from the end of the Atlantic up to the beginning of the Subatlantic (between 7412 and $6987 \mathrm{cal}$. BP up to 3069-2774 cal. BP) indicate a long phase (6I) during which the morphological budget was close to stability. Then, sedimentation increased sharply (7SU) during the Subatlantic, from 3069 to 2774 cal. BP up to 1349-1179 cal. BP or 966-765 cal. BP depending on the site. This thick unit (up to $2 \mathrm{~m}$ ) is composed of various facies, mainly silty but locally OM-rich (oCSi, OCSi, PSi, SiP and rare $\mathrm{CSaSi}$ ) and extends across the whole floodplain. Later, during the last millenium, sedimentation became more detrital: $8 \mathrm{SU}$, with a thickness of 0.6 to $1 \mathrm{~m}$, is composed mainly of oCSi facies, but also PSi, SiP and locally CSaSi.

In stretch A, the NAU and HAR transects show a relatively different pattern of evolution, which also differs from stretches $\mathrm{C}$ and $\mathrm{D}$ (Figs. 5A and 6A). The phases 1I and 2SU (facies GSa) were identified, as in stretches $\mathrm{C}$ and D. During phase 3, the 2SU deposits were incised (3I), the resulting surface being less irregular in transect NAU than in transect HAR (Fig. 2). At NAU, phase 3 developed before the deposition of PSi (phase 4SU) at 12714-12431 cal. BP (Allerød-Younger Dryas transition). This peaty bed is absent at HAR and there are no deposits anywhere in stretch A during phases 5 and 6 identified in stretches $\mathrm{C}$ and $\mathrm{D}$. The morpho-sedimentary budget in the floodplain from the beginning of the Younger Dryas to the Subatlantic was marked by low incision (mainly during 5I and 6I) probably close to stability, particularly upstream in the sub-catchment (NAU). Then, during phase 7, sedimentation developed throughout the floodplain from the Subatlantic (7SU), much earlier downstream in the sub-catchment (3549-3341 cal. BP at HAR) than upstream (a little before 1514-1302 cal. $\mathrm{BP}$ at NAU). 7SU is formed mainly of detrital silt containing sand (CSaSi), with discontinuous debris flow and interbedded slope deposits (NAU). From the High Middle Ages (a little before 1168-936 cal. BP at NAU and 907-695 cal. BP at HAR), deposits are more heterogeneous (8SU), with locally interbedded CSaSi, oCSi, DF and SD facies. While the 7SU and 8SU thicknesses are similar (about $1.5 \mathrm{~m}$ ) at NAU, they vary from $1 \mathrm{~m}$ to more than $2 \mathrm{~m}$ respectively at HAR.

In stretch B (ROC and BIL transects), phases 1I, 2SU (facies GSa), and 3I before 10401$10208 \mathrm{cal}$. BP in transect BIL were identified, the last phase being particularly marked downstream ( $2 \mathrm{~m}$-deep incision). Then, there is no evidence of sedimentation in the upstream part of the sub-catchment (transect ROC) up to the Subatlantic: evolution seems to be marked 
only by low incision, close to morphological stability (5I and 6I). Downstream (transect BIL), the floodplain evolution is more complicated. Phase 4 is testified by OM-rich 4SU deposits (PSi and OCSi) from 10401 to $10208 \mathrm{cal}$. BP (end of the Preboreal) up to at least 96909493 cal. BP (middle of the Boreal), but there was no deposit during phases 5 and 6 (5I and 6I). The location of the 4SU deposits in the palaeochannels cut in 2SU suggests that these organic facies could have reached a thickness of up to $1.5 \mathrm{~m}$ before incision during $5 \mathrm{I}$ and $6 \mathrm{I}$. Phase 7 is characterized by sedimentation (7SU) throughout the floodplain during the Subatlantic from 2945 to 2765 cal. BP at ROC and much earlier, 3688-3477 cal. BP, at BIL. This unit comprises various facies, often OM-rich (CSaSi, PSi, OCSi and oCSi) with interbedded DF and SD. Phase 8 began at 1261-1002 cal. BP at BIL and 927-744 cal. BP at ROC, with deposition of mainly detrital sediments (8SU), which are heterogeneous, often sandy (predominantly CSaSi, with oCSi, OCSi and GSa), and contain interbedded SD and AE. In transect BIL, 8SU contains GSa beds (core BIL1) which are recent (later than 12971093 cal. BP) and probably filling a man-made palaeochannel up to a depth of about $1.5 \mathrm{~m}$. This palaeochannel is close to the present channel whose banks are covered with AE material. The 7SU and 8SU deposits seem to have similar thicknesses: about $1 \mathrm{~m}$ at ROC and from 0.5 to $2 \mathrm{~m}$ at BIL.

\subsection{Spatial variability and forcing factors of the river morpho-sedimentary dynamics}

Fluvial systems being rarely stable (Trimble, 1977), the phases defined above were interpreted as periods of sediment-unit deposition (SU) and/or erosion-incision (I) in the floodplain, elements of the catchment-sediment budget depending on several parameters: the sediment yield in the catchment, the degree of slope-floodplain connection and the fluvial dynamics (Meade et al., 1990). In a small catchment such as the Choisille, these parameters vary in time with climate and human activities, and in space with human activities and local geomorphological factors (e.g. [Rose, 1995], [Macklin, 1999] and [Houben, 2003]). The apparent similarity of the morpho-sedimentary evolution during the Upper Pleistocene phases up to the middle LateGlacial (1I, 2SU and 3I) in all the stretches studied suggests the same pattern of evolution throughout the catchment for this period. Later, the floodplain evolution varies spatially (Fig. 7).

Phase 1 - During the Upper Pleistocene, before $44550 \pm 4580$ yrs (OSL), incision processes (1I) eroded the earlier alluvium and underlying bedrock (Fig. 7). The thick gravelly-sandy deposits of the Palluau terrace, $5 \mathrm{~m}$ above the floodplain and clearly marked by low electric conductivity (Fig. 4), are older than this phase (Early Weichselian or Saalian age?). This incision, which is the latest to cut into the Cretaceous and Eocene limestones in the valley bottom, shows a lower sediment yield from the catchment slopes than the solid-matter discharge capacity of the river downstream. This type of incision indicates efficient soil protection by dense vegetation and high water discharge. It has been observed in many valleys of north-western Europe and interpreted as the result of the climate becoming colder at the beginning of the Weichselian ([Haesaerts, 1984], [van Huissteden et al., 1986] and [Antoine et al., 2007]), particularly during the period between the Early Glacial and the Early Pleniglacial (Mol et al., 2000). The marked increase in incision over a short distance in the downstream part of sub-catchments $\mathrm{A}$ and $\mathrm{B}$, where the elevation of the floodplain surface is the same as that of the top of the calcareous formations of the bedrock, suggests that the groundwater contributed significantly to the river-water supply. Downstream (stretch D), the bedrock incision, which is $5.5 \mathrm{~m}$ deeper than the current floodplain surface, implies a similar incision of the Loire channel $3 \mathrm{~km}$ downstream. 
Phase 2 - It corresponds to the first deposition of the 2SU gravelly-sandy facies in stretch D, dated by OSL at $44550 \pm 4580$ yrs (Weichselian Pleniglacial). These deposits indicate a braided fluvial system ([Reineck and Singh, 1980] and [Bridge, 2003]). Pluricentimetric siliceous rock fragments (flint, silcretes, quartz, bioclasts, etc.) were displaced from the plateaux to the valley bottom, suggesting that they were embedded in an abundant silty-clayey matrix and moved by gelifluxion in cold periglacial conditions ([Haesaerts, 1984] and [Rose, 1995]). The abundance of coarse elements in the sediment yield, as well as the probable increase in water discharge (Schumm, 1985), induced the braided river pattern, the current having carried the clayey-silty fractions and concentrated gravel and sand downstream as bedload. However, the more recent OSL dates (11910 $\pm 1030 \mathrm{yrs}$ and $7860 \pm 650$ in stretch C) obtained in the GSa facies show that the gravel and sand were reworked during the LateGlacial and the Holocene. The Choisille could not easily transport this very coarse bedload, with the result that the polyphased GSa facies can still be observed at the bottom of the floodplain-sediment filling, with no apparent upstream-downstream evolution. The repeated reworking of GSa since the LateGlacial explains why it often contains a marked silty-clayey matrix ( $>10 \%$ of the bulk, excluding gravel), which could not have been deposited systematically in the high energy conditions of a braided system. The increase in quartz and illite group minerals in the $<2 \mu \mathrm{m}$ fraction (Fig. 3) could however be the result of the coarser element breaking up due to the bed-incision process during phase 3 . The aeolian sediments covering the plateaux (Macaire, 1986b) were never observed interbedded in 2SU, in contrast to more northern regions where Pleniglacial or LateGlacial loess or aeolian sand have often been found interbedded in floodplain sediments ([Vandenberghe et al., 1987], [Antoine, 1997], [Lespez et al., 2005] and [Kasse et al., 2007]). That could be due to their absence in initial deposits or a reworking during or after their occurrence.

Phase 3 - It is characterized by incision (3I), indicating a significant change in the hydrosedimentary dynamics at the end of the Pleniglacial and/or the beginning of the LateGlacial. The incision probably ended at the beginning of the Allerød, before the 4SU deposition dated from the Allerød to the Boreal in stretch D, from the Younger Dryas and the Preboreal in stretch C, from the Allerød in stretch A, and from the Preboreal and the Boreal in stretch B (Fig. 5); the river pattern changed from a shifting braided channel to a deep and stable single channel. Incision greatly increased from upstream to downstream in the sub-catchments (higher in B than in A), suggesting the marked contribution of the water tables to the river supply. The coarse sediment yielded by the slopes disappeared due to stabilization of the soil as vegetation developed with climate improvement at the beginning of the LateGlacial, as suggested by many authors (e.g., [Vandenberghe, 1985], [Pastre et al., 1997], [Pastre et al., 2003] and [Antoine et al., 2003]). In the Middle Loire area, palynological data show that wetland taxa increased during the Bölling (Visset et al., 2008). This indicates that precipitation also increased, inducing a rapid change in vegetation, with a response time of 50-100 years (Knox, 1984), and explaining the deep channel incision and floodplain stabilization. The concentration of water flow in a few narrow channels was sufficient to provide the hydraulic energy required to move the $2 \mathrm{SU}$ coarse grains. The irregular shape of the top of this unit, with one main and an occasional secondary channel clearly shown on the conductivity map in stretch D (Fig. 4), indicates that the incision and the stabilization of the fluvial system occurred gradually. The upper beds of the gravelly-sandy $2 \mathrm{SU}$ were probably reworked during that phase.

Phase 4 - It is marked by the deposition of 4SU containing OM-rich facies ( $\mathrm{SiP}$ and PSi), indicating a trend towards conditions favouring wetland vegetation (Phragmites, Carex, etc.), with low-energy water flow and a sustainable high water level in the channel allowing OM 
preservation (Bournerias, 1984). Moreover, the deposition of a detrital clayey-silty fraction (Fig. 3) indicates low sediment yield from the catchment and confirms the fall in water energy. However, the accretion of sediment in the main palaeochannel is low. While OM-rich sedimentation usually develops in abandoned channels or flood basins ([Allen, 1965] and [Bridge, 2003]), it appears almost everywhere in the Choisille valley bottom (particularly in stretches $\mathrm{C}$ and $\mathrm{D}$; transects $\mathrm{BRO}, \mathrm{BJE}$ and CHA respectively; [Fig. 2] and [Fig. 6]), in the deepest active channel where water flowed continually. Consequently, these deposits do not reflect local hydrological conditions, but the systemic hydrological conditions of the river. The 4SU ages range from the Allerød to the Boreal, including the Younger Dryas, providing evidence of the LateGlacial and the beginning of the Holocene both in the Grande Choisille and in the sub-catchments (Fig. 5). Although the climate varied from one chronozone to another during that period ([Bohncke, 1993], [Rose, 1995] and [Limondin-Lozouet et al., 2002]), these changes do not seem to have influenced the hydro-sedimentary conditions, or allowed the deposition of aeolian sediment. This confirms the palynological dataset which indicates that variations in vegetation, and thus climate change, during the LateGlacial were less marked in the Middle Loire area than in other regions of north-western Europe (Visset et al., 2008). The lower river-water discharge compared to phase 3 could be explained by increased evapotranspiration due to the development of arboreal cover (Pinus and/or Betula) at the Allerød, which continued during the Younger Dryas (ibid) and with no marked change at the Preboreal (Visset et al., 2005). The increasing supply of floodplain groundwater to the channels, which were deep at that time, could have buffered the variation of water discharge due to climate change. These bioclimatic and morphological factors can explain the overall stability of the water level in the active channel for about 5000 years, allowing the deposition of peaty sediment. The ${ }^{14} \mathrm{C}$ ages distribution and the absence of $4 \mathrm{SU}$ deposits in some stretches suggest local periods of non-deposition or peat erosion (close to morphological stability) during the Allerød and the Younger Dryas. These periods do not show any clear chronological trend but probably correspond to episodic hydrological events in the active channel. Thus, the local sedimentary gaps in 4SU reflect the spatial variability of the sedimentary record due to fluvial dynamics (autogenic forcing) (Macaire, 1990) rather than climate change during phase 4 . Indeed, in sub-stretches A and B, the lack of 4SU deposits could also be due to their erosion during phases 5I and 6I. The GSa facies could have been reworked during phase 4 as shown by the OSL date of $11910 \pm 1030$ yrs (Younger DryasPreboreal transition) in the main valley (stretch C).

Phase 5 - It covered the end of the Boreal, the Atlantic and the beginning of the Subboreal (from 9276 to $8367 \mathrm{cal}$. BP to 7713-6319 cal. BP) and is characterized by aggradation (5SU) in stretches $\mathrm{C}$ and $\mathrm{D}$ and incision (5I) in sub-catchments $\mathrm{A}$ and $\mathrm{B}$ ([Fig. 5], [Fig. 6] and [Fig. 7]). The unconformity between 4SU and 5SU in stretch $\mathrm{C}$ indicates the gain of hydraulic energy in the channel during phase 5 and the reactivation of channels inherited from phase $3 I$. This hypothesis is supported by the OSL date of $7860 \pm 650$ yrs in the GSa facies (transect POI) suggesting that the underlying gravel and sand were reworked again at that time. In stretches $\mathrm{C}$ and $\mathrm{D}$, increased sediment storage throughout the floodplain could be the result of increased sediment yield from the catchment slopes; however, this is not very likely considering the importance of forest cover which maintained soil protection against erosion at this time (Visset et al., 2005). The slight incision of the valley bottom in stretches A and B, at the same time as the increase in 5SU of sand-size fraction and to a lesser extent of carbonate contents and Cretaceous bioclasts in stretches $\mathrm{C}$ and $\mathrm{D}$, indicate that these sediments were mainly yielded by erosion in talwegs, partly from the sand-rich 2SU sediments and partly from gullying the Cretaceous chalk. However, the high variability of the $<2 \mu \mathrm{m}$ fraction composition indicates different source-rocks, and clay with flint formations may also have 
supplied sand and bioclasts. Although gully formation under forest cover on the plateaux as a consequence of initial clearing (Vanwalleghem et al., 2003) should mainly have eroded the loess cover, as during the following phases 7 and 8, gullying affected the Cretaceous bedrock. This linear erosion in the talwegs was favoured by the hydraulic gradients which were higher in the sub-catchments (9\% in A and 5\% in B on average) than in the Grande Choisille (3\%o on average in $\mathrm{C}$ and $\mathrm{D})$. It also explains the lower preservation of 4SU in the sub-catchments ([Fig. 2] and [Fig. 5]). Downstream sediment storage in stretches $C$ and D reflected a change in fluvial dynamics, first filling in the channels inherited from phase 4 , followed by sedimentation throughout the floodplain, with more and more flood events favourable to particle retention as the channel became shallower. The upstream-downstream evolution of the river dynamics shows more abundant and irregular water discharges, and consequently a more humid climate during that phase.

Phase 6 - It is situated during the Subboreal and the beginning of the Subatlantic (after 77136319 cal. BP and prior to 3549-3341 cal. BP) and is marked by incision in all the stretches studied (6I). In stretches C and D, the irregular shape of the top surface of 5SU (Fig. 6), the lack (except at RIA) of sediments dating from that period, and the very short stratigraphic transition, as shown by datings, between sediment from the first part of the Atlantic (5SU) and sediment from the Subatlantic (7SU), are evidence of the incision in the floodplain of a depth of up to more than $1.5 \mathrm{~m}$. In stretches $\mathrm{A}$ and $\mathrm{B}, 6 \mathrm{I}$ is continuous with $5 \mathrm{I}$. The sharp reduction in sedimentation and the downstream spreading of the incision in $\mathrm{C}$ and $\mathrm{D}$ (Fig. 7) can reflect decreased sediment yield in sub-catchments $\mathrm{A}$ and $\mathrm{B}$ and/or increased solid load discharge of the Grande Choisille. These hydro-sedimentary conditions imply that the soil surface was well-protected by forest which expanded considerably at that time, despite the first signs of deforestation ([Visset et al., 2002] and [Visset et al., 2005]), particularly the rapid development of Alnus encouraging preservation of the floodplain surface and incision of the deep channel, as suggested by Brown (1990). This development also suggests an increase in hydraulic energy through increased precipitation as the climate cooled during the Subboreal, at about 4500 cal. BP ([Barber et al., 1994], [Johnsen et al., 2001] and [Magny et al., 2006]). In stretch $\mathrm{D}$, where the floodplain is wider, the main channel incision led to the abandoning of some channels, such as the RIA palaeochannel, which can be seen on the conductivity map (Fig. 4). In this palaeochannel, the silty and then peaty 6SU sedimentation is not representative of the overall incision trend of the river. It nevertheless shows a high water level, particularly from 5291 to 4875 cal. BP, confirming the humid climate.

Phase 7 - This phase corresponds to 7SU deposition, which could be up to $2 \mathrm{~m}$ thick and spread across the whole floodplain during the first part of the Subatlantic up to about 950900 cal. BP (Middle Ages) ([Fig. 6] and [Fig. 7]). The variety of lithological facies (mainly CSaSi, OCSi, oCSi, and locally PSi and SiP in stretches B and C), sometimes shell-rich, shows a varied fluvial palaeomorphology due to the filling-in progress of the inherited phase 6I deep channels: shallow channels which do not shift much, OM-rich sedimentation in continuous humid depressions such as flood basins, and floodplains. The peaty facies were not located in the main channel, as during phase 4 , but in these depressions. The upstreamdownstream grain-size trend (more sandy in $\mathrm{A}$ and $\mathrm{B}$, and more silty in $\mathrm{C}$ and $\mathrm{D}$, Fig. 3), clearly confirmed by lower electrical conductivity values in stretch A than D (Fig. 4), is the result of the fall in energy triggered by the decrease in hydraulic gradient: the Grande Choisille could not discharge downstream the whole solid load yielded by the sub-catchments. The high abundance of silt in stretches $\mathrm{C}$ and $\mathrm{D}$ indicates that fluvial sediments were mainly supplied by loess, as demonstrated in the Middle Loire region (Macaire et al., 2002). Moreover, the sandy fraction, marked in fluvial sediments of the sub-catchments, seems to 
have come from the aeolian cover which is sand-rich (Macaire, 1986b), rather than from sandrich Cretaceous chalk, as it does not contain bioclasts. In the sub-catchments, even with higher overall slope gradients, the solid load exceeded the discharge capacity of the channel.

The ${ }^{14} \mathrm{C}$ ages at the bottom of 7SU deposits vary spatially and demonstrate a retrograde sedimentary trend (Fig. 8): in the Grande Choisille, dates vary from 3630 to 3376 cal. BP downstream (stretch D, core RIA) to 3069-2774 cal. BP about $12 \mathrm{~km}$ upstream (stretch C, core BRO-S13). In stretches A and B, the retrograde trend of sedimentation is more marked: the beginning of aggradation varies from 3549 to $3341 \mathrm{cal}$. BP downstream (HAR) to 1514 1302 cal. BP upstream (NAU) within a range of $2 \mathrm{~km}$ in A, and long before 3688-3477 cal. BP downstream (BIL) to 2945-2765 cal. BP upstream (ROC) within a range of $3 \mathrm{~km}$ in B. In the downstream parts of these stretches, sedimentation began either earlier than (B), or at the same time as (A) in stretch D, showing that the Grande Choisille discharged only a part of the solid discharge of its tributaries, although early.

The sediment storage triggered at the beginning of the Subatlantic shows a high increase in sediment yield. The climate became more humid in the first part of the Subatlantic ([Barber et al., 1994], [Van Geel et al., 1996] and [Steig, 1999]), favouring forest cover, and should therefore have increased incision of the valley bottom, continuing the dynamics of phase 6 . OM-rich facies, also observed elsewhere in the Middle Loire at that time ([Visset et al., 1999], [Cyprien et al., 2001] and [Macaire et al., 2006]), indicate a rise in the water table which could have been due to increased precipitation. However, in the Choisille catchment, continuous humid depressions could be the result of the autogenic morphological evolution of the floodplain, with increasingly frequent water table outcropping due to the channel becoming shallower in the aggrading fluvial system. The sharp increase in silty sediment yield is probably related to deforestation for crop farming on the plateaux, which started in the Bronze Ages in the Middle Loire ([Cyprien et al., 2004] and [Visset et al., 2005]). This deforestation, together with Alnus cutting in the valley bottom, could have reduced evapotranspiration and thus contributed to the rise in the water table ([Smith and Charman, 1988], [Chapman and Rose, 1991], [Visset et al., 1999] and [Macaire et al., 2006]). The spatial diachronism of the start of the 7SU deposition provides evidence of the impact of deforestation: sedimentation appeared earlier (Final Neolithic? - Early Bronze) in stretch B than stretch A (Middle Bronze). Moreover, the rapid accumulation upstream in B (Fig. 8) shows the very high and continuous sediment yield due to human activities, although dissolved flux should have dominated in that limestone-rich catchment (Meybeck, 1987). Conversely, in sub-catchment A, even with dominant siliceous minerals in the bedrock favouring detritism, the slow retrograde accumulation, which might be favoured by the higher hydraulic gradient (9\%), mainly shows low human impact up to the Early Middle Ages. The earlier and continuous clearing in sub-catchment B can be explained by the quality of mainly carbonated soils, more favourable for cereal cropping than the siliceous soils in sub-catchment A. The high variability of the $<2 \mu \mathrm{m}$ fraction composition (Fig. 3) in A and B indicates the spatio-temporal variability of agricultural stress. In stretch $\mathrm{D}$, the start of sedimentation (Middle-Final Bronze Ages) is a mean time-lagged date considering the duration of solid flux transit from upstream, which smoothes the diachronism of erosion due to anthropisation throughout the catchment. Debris flows and slope deposits, particularly in the sub-catchments where the floodplains are steeper and narrower, confirm that slopes were destabilized by clearing.

Phase 8 - This phase is marked by 8SU deposits which exhibit no clear lithological limit with $7 \mathrm{SU}$; it was observed in all stretches where it spreads across the whole floodplain and can be 
up to $1.5 \mathrm{~m}$ thick (Fig. 6). This phase began at about $950-900$ cal. BP and is characterized by a relative increase in detrital facies. Sediments indicate a fluvial system with a deeper channel, confirmed by signs of oxic conditions in sediments testifying to a lowering of the water table in the floodplain. The retrograde sedimentation trend in sub-catchments A and B (Fig. 7) shows that rivers could not discharge the overall sediment yield which increased sharply during that period. In stretch A the floodplain stored more sediments than in B during that phase, in contrast to phase 7, despite the higher hydraulic gradient. This factor, sometimes evoked to explain why the quantities of stored sediment differ from one valley to another ([Brown, 1990] and [Houben, 2003]), was secondary during phase 8 in the Choisille catchment. The more frequent oCSi facies relative to CSaSi in $8 \mathrm{SU}$, in comparison with 7SU (Fig. 3), confirms the increasing erosion of loessic soils on the plateaux, but could also be the result of the autogenic evolution of fluvial dynamics, with lower sandy than silty overbank supply due to increased channel incision. As during phase 7, slope destabilization is shown by debris flows just downstream of the junction of side talwegs with the floodplain in stretches $\mathrm{A}$ and B, clearly marked by sediment resistivity (Fig. 4), and slope deposits interbedded in fluvial sediments. These observations are in accordance with the limited forest cover from the Middle Ages in the Middle Loire region ([Cyprien et al., 2004] and [Visset et al., 2005]). The decreasing organic sedimentation in all the stretches can be explained by the humid depression infilling by detrital supplies. It could also be the consequence of a lowering of the water table (with sediment-oxidation increasing) due to draining the floodplains to supply mills with water since the 10th century AD in the catchment (Guichané, 2002), and digging the main channel for floodplain exploitation (timber or thatch production, creating pasture). The more OM-rich facies (OCSi) of the pile top correspond to present soils. These humaninduced changes in water and solid fluxes and sedimentation conditions during the last millenium prevent the detection of any climate change effect of the Little Ice Age.

\subsection{Fluvial-system reactivity to the forcing factors and specificity of the Choisille River evolution in north-western Europe}

The eight evolution phases of the Choisille floodplain can be merged into four main periods; the first three were forced by climate changes, and the last was mainly forced by human activities. Since the Last Pleniglacial, tectonics did not influence the morpho-sedimentary floodplain evolution in this area.

During period I (phases 1, 2 and 3), the morpho-sedimentary dataset and OSL datings suggest a new interpretation compared to former data, mainly in relation to the polyphased character of 2SU. In the Middle Loire, the latest major incision into bedrock (phase 1I), attributed to the Middle (Macaire, 1981) or Upper (Carcaud et al., 2002) Weichselian, appears to be prior to the Weichselian Middle Pleniglacial, as observed in the upper Loire (Straffin et al., 1999) and in more northern regions ([Haesaerts, 1984], [van Huissteden et al., 1986] and [Mol et al., 2000]). It can be as early as the Early Glacial (Antoine et al., 2007). The 2SU gravelly-sandy sediments, ubiquitous at the bottom of the floodplain-sediment piles in northwestern Europe, have been dated from the "Middle Weichselian" (Macaire, 1981), from the Late Pleniglacial - LateGlacial transition (Carcaud et al., 2002), or from the first part of the Holocene (Macaire et al., 2002) in the Middle Loire area, and generally from the Weichselian Pleniglacial in the Parisian Basin ([Antoine, 1997] and [Pastre et al., 1997]). In the Choisille catchment, as in numerous north-western European valleys, 2SU was first deposited, at least in part, during the Middle Pleniglacial (Mol et al., 2000). These deposits were more or less reworked, although the palaeohydrological conditions never allowed the overall discharge of these coarse sediments downstream. The main incision phase 3I occurred probably during the 
Bölling as often noted in Western Europe (e.g. [Haesaerts, 1984], [Vandenberghe et al., 1987], [Rose, 1995], [Pastre et al., 1997], [Pastre et al., 2003] and [Antoine et al., 2003]). Although chronological data are still scarce for this period in the Middle Loire area, climate changes during the Weichselian and the Pleniglacial - LateGlacial transition seem to have induced similar morpho-sedimentary dynamics for the Choisille and more northern rivers. However, the periods of high aeolian dynamics are not distinguishable in the Choisille sedimentary record.

Period II corresponds to phase 4, ranging from the beginning of the Allerød to the last third of the Boreal, during which the morphological budget was locally slightly positive (peaty sediments), but close to stability on average. The presence of the Younger Dryas in sediment facies similar to those from the Allerød, Preboreal and Boreal, together with vegetation (Visset et al., 2008), may indicate that climate change was less marked through this period in the Middle Loire area than in more northern areas. The increase in detrital sedimentation ([Rose, 1995], [Pastre et al., 1997], [Pastre et al., 2003], [Andres et al., 2001], [Antoine et al., 2003] and [Orth et al., 2004]) and the aeolian deposits interbedded in fluvial sediments ([Haesaerts, 1984] and [van Huissteden et al., 1986]; [Vandenberghe et al., 1987] and [Mol et al., 2000]) observed during the Younger Dryas in more northern areas are not found in the Choisille catchment. Moreover, there is no evidence of the changes in river patterns suggested in the south-western Parisian Basin after the Allerød (Visset et al., 2005) or during the LateGlacial-Holocene transition (Carcaud et al., 2002), as testified in numerous sites in the Parisian Basin ([Pastre et al., 1997], [Antoine et al., 2003] and [Orth et al., 2004]) and northwestern Europe ([Vandenberghe et al., 1994] and [Mol et al., 2000]). The channel patterns inherited from phase 4 continued with no significant change throughout the Choisille floodplain (Fig. 7) up to the second part of the Boreal when the forest cover significantly developed. The particular evolution of the Choisille River during that period, as during period I, seems to be the result of the climate trend in the south-western Parisian Basin relative to more northern areas, which can be explained by the proximity of the Atlantic Ocean. Indeed, the middle and northern parts of the Parisian Basin, as in north-western Europe, could have experienced more contrasted continental climate as a result of the absence of the North Sea and the English Channel due to the lowering of the sea level, as suggested by Bohncke (1993).

Period III, which corresponds to phases 5 and 6, is characterized by both incision and deposition processes in the floodplain from the end of the Boreal up to the beginning of the Subatlantic. The 5SU deposition in the Grande Choisille is related to incision (5I) in the subcatchments. As the moderate incision became widespread in the floodplain during the Subboreal (phase 6), the sedimentation was limited to palaeochannels, like the abandoned one at RIA, in the downstream part of the fluvial system. The spatial variability of the morphosedimentary dynamics (incision upstream, sedimentation downstream) during phase 5 can explain the varied local observations made in the Middle Loire and its tributaries: absence or presence of mainly detrital sediment during the Boreal, the Atlantic or the Subboreal ([Visset et al., 1999], [Carcaud et al., 2000], [Carcaud et al., 2002], [Cyprien et al., 2001] and [Macaire et al., 2006]). The eustatic variations suggested by Visset et al. (1999) and Carcaud et al. (2000) to explain the fluvial dynamics in some sites of the Middle Loire at that time could not have influenced the Choisille which is too far from the ocean (about $200 \mathrm{~km}$ ). The solid flux increase during phase 5 reflects a trend to a more humid climate despite the brief cold and dry climatic event at 8200 cal. BP ([Denton and Karlén, 1973], [Von Grafenstein et al., 1999], [Johnsen et al., 2001] and [Alley and Agustsdottir, 2005]). The continuous humidity and the development of forest cover due to improved climate (Visset et al., 2005), particularly the development of Alnus in the floodplain during the Subboreal, can explain the decreased solid 
load and increased incision during that period. Consequently, the Choisille base level, i.e. the Loire channel, certainly rose during phase 5 , then fell during phase 6 . This differs from the pattern proposed by Arnaud-Fassetta et al. (2010) for the Touraine area. It also differs greatly from the trends observed in more northern areas where the Boreal, the Atlantic and sometimes a part of the Subboreal are marked by the accumulation of peaty sediment ([Rose et al., 1980], [Haesaerts, 1984] and [Vandenberghe et al., 1984]), often with precipitated carbonates in the Parisian Basin ([Antoine, 1997], [Pastre et al., 1997], [Pastre et al., 2002a], [Orth et al., 2004] and [Lespez et al., 2005]), showing low water energy and morphological stability. Theses differences might be due to internal forcing, even if hydraulic gradients (3-9\%o) are similar to those of the Parisian Basin rivers. The lack of precipitated carbonates in the Choisille sediments, as generally found in sediments in the Middle Loire area during the Holocene, can be explained by the relatively low carbonate content of the chalks of the Touraine region, which are conversely quartzous-sand rich (Rasplus and Alcaydé, 1974); this is confirmed by the low dissolved carbonate contents in the Loire catchment rivers as opposed to the middle Parisian Basin rivers (Meybeck and Ragu, 1996). Peaty sediments, generally widespread in the Middle Loire area at that time, are not found here; the reason for this is not clear. It does not seem to be the result of unfavourable climatic conditions, because climate was more humid at that time and similar peaty deposits have been observed later ([Visset et al., 1999], [Cyprien et al., 2001] and [Macaire et al., 2006]). It could be due to specific Loire-catchment morphological factors, such as continuous deep channels, even during $5 \mathrm{SU}$.

Period IV, comprising phases 7 and 8, is characterized by the considerable development of mainly silty detrital sedimentation, which seems to be due to deforestation for crop farming. In the small Middle-Loire catchments, while the first indicators of agriculture appeared during the Mesolithic-Neolithic transition (Visset et al., 2002), their consequences on soil erosion and fluvial sedimentation appeared at different times according to the area studied: the Middle Neolithic (Macaire et al., 2006), the Middle Bronze Ages ([Visset et al., 1999] and [Cyprien et al., 2001]), and more markedly in Gallo-Roman times (Carcaud et al., 2002). Similar observations have been made in north-western Europe (e.g. [Vandenberghe et al., 1984], [Brown, 1990], [Macklin and Needham, 1992] and [de Moor et al., 2008]). In the Choisille catchment, human-induced sedimentation first appeared in the sub-catchments, in line with the observations of Pastre et al. (1997). Moreover, the ages of the 7SU bottom vary from upstream to downstream (Fig. 8): the sediment yield increase enhanced sedimentation in the downstream parts of the sub-catchments, creating a sediment storage that the Grande Choisille could not completely remove. Detrital sedimentation appeared suddenly and markedly, in contrast to the steady increase during the Subboreal in continuation of the peaty Atlantic sedimentation in small catchments of the more northern Parisian Basin (Pastre et al., 2002b). These authors and Orth et al. (2004) observed either no sedimentation, without any incision trend, or organic or detrital sedimentation during the Subboreal and the Subatlantic alternately: detrital sedimentation appeared at different periods during the Bronze Ages, increasing noticeably during the Second Iron Age, occasionally during and principally after the Middle Ages (Antoine, 1997). These authors explain these hydro-sedimentary variations as the result of human activity or climate change, or sometimes both. In the Choisille catchment, the OM-rich sediments (7SU) - silt-rich detrital sediments (8SU) sequence is similar to observations in the Parisian Basin and could reflect a global climate impact. However, in the Choisille catchment, period IV began at about $3900 \mathrm{cal}$. BP (Fig. 5), and the boundary between 7SU and $8 \mathrm{SU}$ is dated at about $950-900 \mathrm{cal}$. BP, as observed elsewhere in the Middle Loire area by Visset et al. (1999). These boundary dates correspond neither to the dates, varying according to sites, observed in the more northern Parisian Basin, nor to the main periods of climate change to cooler and more humid climate at about $4500 \mathrm{cal}$. BP and 
2600 cal. BP ([Barber et al., 1994], [Van Geel et al., 1996], [van Geel et al., 1998], [Steig, 1999] and [Johnsen et al., 2001]). Indeed, the impact of climate change on fluvial dynamics is not demonstrated in the Choisille catchment. The start of sedimentation during the Subatlantic, differing between and within each stretch, seems to indicate the probable spatio-temporal irregularity of deforestation; more generally, the non-univocal upstream-downstream variation of the age of a sediment-unit bottom indicates that this unit is human-induced. The disappearance of wetlands during the Subatlantic seems to be the result of both morphological changes related to floodplain accretion and hydraulic works since the Middle Ages ([Burnouf and Carcaud, 1999], [Guichané, 2002] and [Macaire et al., 2006]). Thus, period IV is more marked by local human activities than by global climate change.

\section{Conclusion}

The spatio-temporal analysis of the floodplain-sediment infilling throughout the Choisille catchment from the Weichselian highlights the various expressions of the fluvial system response to global climate change and human activities, and enables the local catchmentfactor impact on the sedimentary record to be estimated. The evolution of the Choisille River differs significantly from rivers of more northern areas of the Parisian Basin and northwestern Europe; it expresses less contrasted climate change, as already noted from older Quaternary deposits ([Macaire, 1981], [Macaire, 1986a] and [Macaire, 1986b]), and shows the impact of the physiographical characteristics of the Middle Loire area. During the Weichselian and up to the Bölling, the Choisille morpho-sedimentatry evolution is similar to that of north-western Europe rivers: after the latest incision phase into the bedrock (1I), the gravelly-sandy unit (2SU), ubiquitous in the floodplain bottom in north-western Europe, was first deposited during the Middle Pleniglacial, and then deeply incised (3I), probably during the Bölling. However, the lack of aeolian deposits interbedded in fluvial sediments, as the limited aeolian sediment cover in the catchment, mainly indicates a less cold and dry climate than in more northern areas at that time. The 2SU sediments were reworked several times during the LateGlacial and the Holocene. After the Bölling and during the Holocene up to the Subatlantic, the evolution of the Choisille differed markedly from that of more northern rivers. The morpho-sedimentary evolution of the floodplain does not reflect clear climate change from the Allerød up to the last third of the Boreal, probably because the climate was continuously moderately cold and dry, with no marked change, in contrast to more northern areas. Sedimentation, mainly peaty (4SU) with a slight accreting trend, is located in the main channel, with no detrital deposition increase during the Younger Dryas, and no appearance of the incision often described in north-western Europe at the LateGlacial-Holocene transition. The palaeoclimatic specificity (temperate trend) of the south-western Parisian Basin during the late Weichselian up to about the end of the Boreal shows the impact of the nearby Atlantic Ocean and probably the southern gradient, in comparison with the more northern areas where the climate was more continental. The moderate incision of channels, spreading from upstream sub-catchments to the main valley from the end of the Boreal up to the Subatlantic (5I and 6I), clearly reflects increased precipitation and vegetation cover. This period is also unusual in that the widespread peat deposition common in north-western Europe did not occur, nor were there any precipitated carbonates in 5SU sediments, although they are frequent in the Parisian Basin. These lithological particularities seem to be the result of local physiographical characteristics, i.e. the deep incision of the Loire channel inducing continuous dynamic flow in its tributary, and of the lithology of the Choisille catchment bedrocks which are quartzeous silt and sand-rich as in the whole Loire catchment. During the Subatlantic, the main period of retrograde sedimentary accretion in the floodplain (7SU and 8SU), deposition was triggered by deforestation for crop farming on the plateaux. Due to high human-induced sediment yield 
and storage, no evidence of any climate change impact on fluvial dynamics can be seen. The beginning of this period and the increasing intensity of human impact vary from one subcatchment to another, due to their specific agricultural quality. Moreover, the upstreamdownstream variation in age of the 7SU bottom is irregular and non-univocal, an observation which could be used more generally to detect human-induced sedimentation in other catchments. Later, the evolution of the sediment facies (7SU to 8SU) can only be explained by an autogenic morphological human-induced evolution of the accreting floodplain.

\section{Acknowledgments}

This work was supported by the French CNRS-INSU ECLIPSE programs 'Impact anthropique sur l'érosion des sols et la sédimentation dans les zones humides associées durant l'Holocène' and Zone Atelier Loire. We thank I. Pène, J.R. Disnar, and many other collaborators for their help in acquiring field data and sediment analysis. We thank Elizabeth Yates for her assistance translating this text. We thank two anonymous reviewers for their constructive comments.

\section{References}

Allen, 1965 J.R.L. Allen, A review of the origin and characteristics of recent alluvial sediments, Sedimentology 5 (1965), pp. 89-191.

Alley and Agustsdottir, 2005 R.B. Alley and A.M. Agustsdottir, The 8k event: cause and consequences of a major Holocene abrupt climate change, Quaternary Science Reviews $\mathbf{2 4}$ (2005), pp. 1123-1149.

Andres et al., 2001 W. Andres, J.A.A. Bos, P. Houben, A.J. Kalis, S. Nolte, H. Rittweger and J. Wunderlich, Environmental change and fluvial activity during the Younger Dryas in central Germany, Quaternary International 79 (2001), pp. 89-100.

Antoine, 1997 P. Antoine, Modifications des systèmes fluviatiles à la transition Pléniglaciaire-Tardiglaciaire et à l'Holocène: l'exemple du bassin de la Somme (Nord de la France), Géographie physique et Quaternaire 51 (1997), pp. 93-106.

Antoine et al., 2003 P. Antoine, A.V. Munaut, N. Limondin-Lozouet, P. Ponel, J. Dupéron and M. Dupéron, Response of the SelleRiver to climatic modifications during the Lateglacial and early Holocene (Somme basin-northern France), Quaternary Science Reviews 22 (2003), pp. 2061-2076.

Antoine et al., 2007 P. Antoine, N. Limondin-Lozouet, C. Chaussé, J.P. Lautridou, J.F. Pastre, P. Auguste, J.J. Bahain, C. Falguères and B. Galehb, Pleistocene fluvial terraces from northern France (Seine, Yonne, Somme): synthesis, and new results from interglacial deposits, Quaternary Science Reviews 26 (2007), pp. 2701-2723.

Archie, 1942 G.E. Archie, The electrical resistivity log as an aid in determining some reservoir characteristics, Transactions of the American Institute of Mining and Metallurgical Engineers/Petroleum Division 146 (1942), pp. 54-62.

Arnaud-Fassetta et al., 2010 G. Arnaud-Fassetta, N. Carcaud, C. Castanet and P.-G. Salvador, Fluviatile palaeoenvironment in archaeological context: geographical position, 
methodological approach and global change - Hydrological risk issues, Quaternary International 216 (2010), pp. 93-117.

Barber et al., 1994 K.E. Barber, F.M. Chambers, D. Maddy, R. Stoneman and J.S. Brew, A sensitive high-resolution record of late Holocene climatic change from a raised bog in northern England, The Holocene 4 (1994), pp. 198-205

Bohncke, 1993 S.J.P. Bohncke, Lateglacial environmental changes in the Netherlands: spatial and temporal patterns, Quaternary Science Reviews 12 (1993), pp. 707-717.

Bournerias, 1984 M. Bournerias, Guide de végétaux de la région parisienne, Masson, Paris (1984).

Bridge, 2003 J.S. Bridge, Rivers and Floodplains - Forms, Processes and Sedimentary Record, Blackwell Science (2003).

Brown, 1990 A.G. Brown, Holocene floodplain diachronism and inherited downstream variations in fluvial processes: a study of the river Perry, Shroshire, England, Journal of Quaternary Science 5 (1990), pp. 39-51

Brown, 1997 A.G. Brown, Alluvial Geoarchaeology: floodplain archaeology and environmental change, Cambridge University Press, Cambridge (1997).

Brown and Keough, 1992 A.G. Brown and M.K. Keough, Palaeochannels and palaeolandsurfaces: the geoarchaeological potential of some Midland floodplains. In: S. Needham and M.G. Macklin, Editors, Alluvial Archaeology in Britain, Oxford Monograph 27, Oxbow Press, Oxford (1992), pp. 185-196.

Burnouf and Carcaud, 1999 J. Burnouf and N. Carcaud, Le val de Loire en Anjou Touraine: un cours forcé par les sociétés riveraines, Médiévales 36 (1999), pp. 17-29.

Carcaud et al., 2000 N. Carcaud, A.L. Cyprien and L. Visset, Marais et vallées de la Loire, mémoire des paysages depuis dix mille ans. Etude comparative des marais de Distré et Champtocé et de la vallée de la Loire à Montjean-sur-Loire, Archives d'Anjou 4 (2000), pp. 187-215.

Carcaud et al., 2002 N. Carcaud, M. Garcin, L. Visset, J. Musch and J. Burnouf, Nouvelle lecture de l'évolution des paysages fluviaux à l'holocène dans le bassin de la Loire moyenne. In: J.P. Bravard and M. Magny, Editors, Les fleuves ont une histoire, paléo-environnement des rivières et des lacs français depuis 15000 ans, Errance, Paris (2002), pp. 71-84.

Castanet, 2008 Castanet, C., 2008. La Loire en Val d'Orléans. Dynamiques fluviales et socioenvironnementales durant les derniers 30000 ans: de l'hydrosystème à l'anthroposystème. Ph.D. Thesis, Université Paris 1, France.

Chapman and Rose, 1991 S.B. Chapman and R.J. Rose, Change in the vegetation at Coon Rigg Moss National Nature Reserve within the period 1958-86, Journal of Applied Ecology 28 (1991), pp. 140-153. 
Cyprien et al., 2001 A.L. Cyprien, N. Carcaud and L. Visset, Etude paléoenvironnementale du Marais de Distré (Saumurois): géoarchéologie d'une zone humide depuis le Préboréal, Quaternaire 12 (2001), pp. 89-101.

Cyprien et al., 2004 A.L. Cyprien, L. Visset and N. Carcaud, Evolution of vegetation landscapes during the Holocene in the central and downstream Loire basin (Western France), Vegetation History and Archaeobotany 13 (2004), pp. 181-196.

Cyprien-Chouin et al., 2004 Cyprien-Chouin, A.L., Visset, L., Carcaud, N., Charrieau, L., 2004. Etudes palynologiques du site de la Grande Brousse, Vallée de la Choisille, Communes de Cérelles et Chanceaux-sur-Choisille (Indre-et-Loire). Rapport Définitif. Analysis Report, Université de Nantes, France.

de Moor et al., 2008 J.J.W. de Moor, C. Kasse, R. van Balen, J. Vandenberghe and J. Wallinga, Human and climate impact on catchment development during the Holocene - Geul River, the Netherlands, Geomorphology 98 (2008), pp. 316-339.

Denton and Karlén, 1973 G.H. Denton and W. Karlén, Holocene climatic variations-Their pattern and possible cause, Quaternary Research 3 (1973), pp. 155-174.

Duchaufour, 1983 P. Duchaufour, Pédologie, 1-Pédogenèse et classification, Masson, Paris (1983).

Erkens et al., 2009 G. Erkens, R. Dambeck, K.P. Volleberg, M.T.I.J. Bouman, J.A.A. Bos, K.M. Cohen, J. Wallinga and W.Z. Hoek, Fluvial terrace formation in the northern Upper Rhine Graben during the last 20,000 years as a result of allogenic controls and autogenic evolution, Geomorphology 103 (2009), pp. 476-495.

Froese et al., 2005 D.G. Froese, D.G. Smith and D.T. Clement, Characterizing large river history with shallow geophysics: middle Yukon River, Yukon Territory and Alaska, Geomorphology 67 (2005), pp. 391-406.

Garcin et al., 1999 M. Garcin, D. Giot, G. Farjanel, J.C. Gourry, W. Kloppman and P. Négrel, Géométrie et âge des alluvions du lit majeur de la Loire moyenne, exemple du Val d'Avaray (Loir et Cher, France), Comptes Rendus de l'Académie des Sciences - Series IIA - Earth and Planetary Science 329 (1999), pp. 405-412.

Gourry et al., 2003 J.C. Gourry, F. Vermeersch, M. Garcin and D. Giot, Contribution of geophysics to the study of alluvial deposits: a case study in the Val d'Avaray area of the River Loire, France, Journal of Applied Geophysics 54 (2003), pp. 35-49.

Guichané, 2002 Guichané, R., 2002. Le savoir des constructeurs de moulins hydrauliques et l'équipement des cours d'eau en Touraine du Moyen-Age à l'époque subcontemporaine. Ph.D. Thesis, Université de Tours, France.

Haesaerts, 1984 P. Haesaerts, Les formations fluviatiles pléistocènes du bassin de la Haine (Belgique), Bulletin de l'Association française pour l'étude du Quaternaire 21 (1984), pp. 1926. 
Hinschberger et al., 2006 F. Hinschberger, A. Fourmont, J.J. Macaire, J.G. Bréhéret, R. Guérin and J.P. Bakyono, Contribution of geophysical surveys to the study of fine grained lacustrine sediments. Application to the Sarliève marsh (Massif Central, France), Bulletin de la Société Géologique de France 177 (2006), pp. 311-322.

Houben, 2003 P. Houben, Spatio-temporally variable response of fluvial systems to Late Pleistocene climate change: a case study from central Germany, Quaternary Science Reviews 22 (2003), pp. 2125-2140.

Jeanroy, 1983 Jeanroy, E., 1983. Diagnostic des formes du fer dans les pédogenèses tempérées. Ph.D. Thesis, Université de Nancy 1, France.

Johnsen et al., 2001 S.J. Johnsen, D. Dahl-Jensen, N. Gundestrup, J.P. Steffensen, H.B. Clausen, H. Miller, V. Masson-Delmotte, A.E. Sveinbjörnsdottir and J. White, Oxygene isotope and paleotemperature records from six Greenland ice-core stations: Camp Century, Dye-3, GRIP, GISP2, Renland and NorthGRIP, Journal of Quaternary Science 16 (2001), pp. 299-307.

Kasse et al., 2007 C. Kasse, J. Vandenberghe, F. De Corte and P. Van Den Haute, Late Weichselian fluvio-aeolian sands and coversands of the type locality Grubbenvorst (southern Netherlands): sedimentary environments, climate record and age, Journal of Quaternary Science 22 (2007), pp. 695-708

Knox, 1984 J.C. Knox, Responses of river systems to Holocene climate. In: H.E. Wright, Editor, Late Quaternary Environments of the United States, The Holocene vol. 2, Longman, London (1984), pp. 26-41.

Lespez et al., 2005 L. Lespez, M. Clet-Pellerin, N. Limondin-Lozouet, J.F. Pastre and M. Fontugne, Discontinuités longitudinales des dynamiques sédimentaires holocènes dans les petites vallées de l'ouest du Bassin parisien, l'exemple de la Mue (Basse Normandie), Quaternaire 16 (2005), pp. 273-298.

Limondin-Lozouet et al., 2002 N. Limondin-Lozouet, A. Bridault, C. Leroyer, P. Ponel, P. Antoine, C. Chaussé, A.V. Munaut and J.F. Pastre, Evolution des écosystèmes de fond de vallée en France septentrionale au cours du Tardiglaciaire: l'apport des indicateurs biologiques. In: J.P. Bravard and M. Magny, Editors, Histoire des rivières et des lacs de Lascaux à nos jours, Errance, Paris (2002), pp. 45-62.

Macaire, 1981 Macaire, J.J., 1981. Contribution à l'étude géologique et paléopédologique du Quaternaire dans le Sud-Ouest du bassin de Paris (Touraine et ses abords). Ph.D. Thesis, Université de Tours, Tours, France.

Macaire, 1986a J.J. Macaire, Sequence of polycyclic soils formed on Plio-Quaternary alluvial deposits in south-western Paris Basin (France): paleoecological significance, Catena 13 (1986), pp. 29-46.

Macaire, 1986b J.J. Macaire, Apport de l'altération superficielle à la stratigraphie - Exemple des formations alluviales et éoliennes plio-quaternaires de Touraine (France), Bull. Ass. Fr. Et. Quat 3 (1986), pp. 233-245. 
Macaire, 1990 J.J. Macaire, L'enregistrement du temps dans les dépôts fluviatiles superficiels: de la géodynamique à la chronostratigraphie, Quaternaire 1 (1990), pp. 41-49.

Macaire et al., 2002 J.J. Macaire, S. Bellemlih, C. Di-Giovanni, P. De Luca, L. Visset and J. Bernard, Sediment yield and storage variations in the Negron River catchment (south-western Parisian Basin, France) during the Holocene period, Earth Surface Processes and Landforms 27 (2002), pp. 991-1009.

Macaire et al., 2006 J.J. Macaire, J. Bernard, C. Di-Giovanni, F. Hinschberger, N. LimondinLozouet and L. Visset, Quantification and regulation of organic and mineral sedimentation in a Late Holocene floodplain as a result of climatic and human impacts (the Taligny marsh, Parisian Basin, France), The Holocene 16 (2006), pp. 647-660.

Macklin, 1999 M.G. Macklin, Holocene river environment in prehistoric Britain: human interaction and impact, Quaternary Proceedings 7 (1999), pp. 521-530.

Macklin and Needham, 1992 M.G. Macklin and S. Needham, Studies in alluvial archaeology: potential and prospect. In: S. Needham and M.G. Macklin, Editors, Alluvial Archaeology in Britain, Oxford Monograph 27, Oxbow Press, Oxford (1992), pp. 9-23.

Magny et al., 2006 M. Magny, U. Leuzinger, S. Bortenschlager and J.N. Haas, Tripartite climate reversal in central Europe 5600-5300 years ago at Arbon-Bleiche, Switzerland, Quaternary Research 65 (2006), pp. 3-19.

Mangerud et al., 1974 J. Mangerud, S.T. Andersen, B.E. Berglund and J.J. Donner, Quaternary stratigraphy of Norden, a proposal for terminology and classification, Boreas 3 (1974), pp. 109-126.

McNeil, 1980 J.D. McNeil, Electromagnetic Terrain Conductivity Measurements at Low Induction Numbers - Technical note TN-6, Geonics, Mississauga (1980).

Meade et al., 1990 R.H. Meade, T.R. Yuzyk and T.J. Day, Movement and storage of sediment in rivers of the United States and Canada. In: M.G. Wolman and H.C. Riggs, Editors, Surface Water Hydrology, The Geological Society of America, Boulder (1990), pp. 255-280.

Meybeck, 1987 M. Meybeck, Global chemical weathering of surficial rocks estimated from river dissolved loads, American Journal of Science 287 (1987), pp. 401-428

Meybeck and Ragu, 1996 M. Meybeck and A. Ragu, River Discharges to the Oceans. An Assessment of Suspended Solids, Major Ions, and Nutrients. Environment Information and Assessment Rpt, UNEP, Nairobi (1996) p. 250.

Mol et al., 2000 J. Mol, J. Vandenberghe and C. Kasse, River response to variations of periglacial climate in mid-latitude Europe, Geomorphology 33 (2000), pp. 131-148.

Murray and Wintle, 2000 A.S. Murray and A.G. Wintle, Luminescence dating of quartz using an improved single-aliquot regenerative-dose protocol, Radiation Measurements 32 (2000), pp. 57-73. 
Orth et al., 2004 P. Orth, J.F. Pastre, A. Gauthier, N. Limondin-Lozouet and S. Kunesch, Les enregistrements morphosédimentaires et biostratigraphiques des fonds de vallée du bassin de la Beuvronne (Bassin parisien, Seine et Marne, France): perception des changements climatoanthropiques à l'Holocène, Quaternaire 15 (2004), pp. 285-298.

Pastre et al., 1997 J.F. Pastre, M. Fontugne, C. Kuzucuoglu, C. Leroyer, N. LimondinLozouet, M. Talon and N. Tisnérat, L'évolution tardi et postglaciaire des lits fluviaux au nord-est de Paris (France). Relations avec les données paléoenvironnementales et l'impact anthropique sur les versants. Géomorphologie: relief, processus, environnement vol. 4 (1997) 291-312.

Pastre et al., 2002a J.F. Pastre, C. Leroyer, N. Limondin-Lozouet, P. Orth, C. Chaussé, M. Fontugne, A. Gauthier, S. Kunesch, Y. Le Jeune and M.C. Saad, Variations paléoenvironmentales et paléohydrologiques durant les 15 derniers millénaires: les réponses morphosédimentaires des vallées du Bassin Parisien (France). In: J.P. Bravard and M. Magny, Editors, Histoire des rivières et des lacs de Lascaux à nos jours, Errance, Paris (2002), pp. 45-62.

Pastre et al., 2002b J.F. Pastre, C. Leroyer, N. Limondin-Lozouet, M. Fontugne, C. Hatté, V. Krier, S. Kunesch and M.C. Saad, L'Holocène du Bassin parisien: variations environnementales et réponses géoécologiques des fonds de vallées. In: H. Richard and A. Vignot, Editors, Equilibres et ruptures dans les écosystèmes durant les 20 derniers millénaires en Europe de l'ouest, Annales littéraires vol. 730, Presses Universitaires FrancContoises, Besançon (2002), pp. 61-73 3.

Pastre et al., 2003 J.F. Pastre, N. Limondin-Lozouet, C. Leroyer, P. Ponel and M. Fontugne, River system evolution and environmental changes during the Lateglacial in the Paris Basin (France), Quaternary Science Reviews 22 (2003), pp. 2177-2188.

Rasplus and Alcaydé, 1974 L. Rasplus and G. Alcaydé, Carte géologique de la France à 1/50000ème, feuille Tours n 457 et notice, Editions du B.R.G.M (1974).

Reimer et al., 2009 P.J. Reimer, M.G.L. Baillie, E. Bard, A. Bayliss, J.W. Beck, P.G. Blackwell, C. Bronk Ramsey, C.E. Buck, G.S. Burr, R.L. Edwards, M. Friedrich, P.M. Grootes, T.P. Guilderson, I. Hajdas, T.J. Heaton, A.G. Hogg, K.A. Hughen, K.F. Kaiser, B. Kromer, F.G. McCormac, S.W. Manning, R.W. Reimer, D.A. Richards, J.R. Southon, S. Talamo, C.S.M. Turney, J. van der Plicht and C.E. Weyhenmeyer, IntCal09 and Marine09 radiocarbon age calibration curves, 0-50,000 years cal BP, Radiocarbon 51 (2009), pp. 11111150 .

Reineck and Singh, 1980 H.E. Reineck and I.B. Singh, Depositional Sedimentary Environments (second ed..), Springer Verlag, Berlin (1980).

Rose et al., 1980 J. Rose, C. Turner, G.R. Coope and M.D. Bryan, Channel changes in a lowland river catchment over the last 13,000 years. In: R.A. Cullingford, D.A. Davidson and J. Lewin, Editors, Timescales in Geomorphology, Wiley, Chichester (1980), pp. 159-175.

Rose, 1995 J. Rose, Lateglacial and Early Holocene river activity in lowland Britain. In: B. Frenzel, Editor, European River Activity and Climate Change during the Lateglacial and 
Early Holocene. ESF Project "European Palaeoclimate and Man” (1995) Special issue 9. Paläoklimaforschung vol. 14, pp. 51-74.

Schumm, 1985 S.A. Schumm, Patterns of alluvial rivers, Annual Review of Earth and Planetary Sciences 13 (1985), pp. 5-27.

Smith and Charman, 1988 R.S. Smith and D.J. Charman, The vegetation of upland mires within conifer plantations in Northumberland, northern England, Journal of Applied Ecology 25 (1988), pp. 579-594.

Starkel, 1991 L. Starkel, Long-distance correlation of fluvial events in the temperate zone. In: L. Starkel, K.J. Gregory and J.B. Thornes, Editors, Temperate Palaeohydrology, Wiley and Sons Ltd (1991), pp. 473-495.

Steig, 1999 E.J. Steig, Mid-Holocene climate change, Science 286 (1999), pp. 1485-1487.

Straffin et al., 1999 E.C. Straffin, M.D. Blum, A. Colls and S. Stokes, Alluvial stratigraphy of the Loire and Arroux rivers (Burgundy, France), Quaternaire 10 (1999), pp. 271-282

Stuiver and Reimer, 1993 M. Stuiver and P.J. Reimer, Extended 14C database and revised CALIB radiocarbon calibration program, Radiocarbon 35 (1993), pp. 215-230.

Taylor and Lewin, 1996 M.P. Taylor and J. Lewin, River behaviour and Holocene alluvial sedimentation: the River Severn at Welshpool, mid-Wales, U.K, Earth Surface Processes and Landforms 21 (1996), pp. 77-91

Trimble, 1977 S.W. Trimble, The fallacy of stream equilibrium in contemporary denudation studies, American Journal of Science 277 (1977), pp. 876-887.

Van Geel et al., 1996 B. Van Geel, J. Buurman and H.T. Waterbolk, Archaeological and palaeological indications of an abrupt climate change in The Netherlands, and evidence for climatological teleconnections around 2650 BP, Journal of Quaternary Science 11 (1996), pp. 451-460.

van Geel et al., 1998 B. van Geel, J. van der Plicht, M.R. Kilian, E.R. Klaver, J.H.M. Kouwenberg, H. Renssen, I. Reynaud-Farrera and H.T. Waterbolk, The sharp rise of $\Delta \mathrm{C} 14 \mathrm{ca}$. 800 cal BC: possible causes, related climatic teleconnections and the impact on human environments, Radiocarbon 40 (1998), pp. 535-550.

van Huissteden et al., 1986 J. van Huissteden, L. van der Valk and J. Vandenberghe, Geomorphological evolution of a lowland valley system during the Weichselian, Earth Surface Processes and Landforms 11 (1986), pp. 207-216.

Vandenberghe, 1985 J. Vandenberghe, Paleoenvironment and stratigraphy during the last Glacial in Belgium-Dutch border region, Quaternary Research 24 (1985), pp. 23-38.

Vandenberghe et al., 1984 J. Vandenberghe, P. Paris, C. Kasse, M. Gouman and L. Beyens, Paleomorphological and botanical evolution of small lowland valleys, Catena 11 (1984), pp. 229-238. 
Vandenberghe et al., 1987 J. Vandenberghe, S. Bohncke, W. Lammers and L. Zilverberg, Geomorphology and palaeoecology of the Mark valley (southern Nederland): geomorphological valley development during the Weichselian and Holocene, Boreas 16 (1987), pp. 55-67.

Vandenberghe et al., 1994 J. Vandenberghe, C. Kasse, S. Bohncke and S. Kozarski, Climaterelated river activity at the Weichselian-Holocene transition: a comparative study of the Warta and Maas rivers, Terra Nova 6 (1994), pp. 476-485.

Vanwalleghem et al., 2003 T. Vanwalleghem, M. Van Den Eeckhaut, J. Poesen, J. Deckers, J. Nachtergaele, K. Van Oost and C. Slenters, Characteristics and controlling factors of old gullies under forest in a temperate humid climate: a case study from the Meerdaal Forest (Central Belgium), Geomorphology 56 (2003), pp. 15-29.

Visset et al., 1999 L. Visset, C. Pont, N. Carcaud, J. Bernard and J.M. Violot, Etude paléoenvironnementale de la vallée du Lane du Néolithique au Moyen-Age, Quaternaire 10 (1999), pp. 247-261.

Visset et al., 2002 L. Visset, A.L. Cyprien, N. Carcaud, A. Ouguerram, D. Barbier and J. Bernard, Les prémices d'une agriculture diversifiée à la fin du Mésolithique dans le Val de Loire (Loire armoricaine, France), Comptes Rendus Palevol 1 (2002), pp. 51-58.

Visset et al. 2005 L. Visset, A.L. Cyprien, N. Carcaud, J. Bernard and A. Ouguerram, Paysage végétal dans le bassin de la Loire moyenne du Tardiglaciaire à l'Actuel, J. Bot. Soc. France 29 (2005), pp. 41-51.

Visset et al., 2008 L. Visset, A.L. Cyprien and N. Carcaud, Essai sur la végétation tardiglaciaire dans le bassin de la Loire moyenne et de ses marges, Revue Archéologique du Loiret 32 (2008), pp. 149-161.

Von Grafenstein et al., 1999 U. Von Grafenstein, H. Erlenkeuser, A. Brauer, J. Jouzel and S.J. Johnsen, A Mid-European decadal isotope-climate record from 15,500 to 5000 years BP, Science 284 (1999), pp. 1654-1657

Walling et al., 1996 D.E. Walling, Q. He and A.P. Nicholas, Floodplains as supended sediment sinks. In: M.G. Anderson, D.E. Walling and P.D. Bates, Editors, Floodplain Processes, J. Wiley, Chichester (1996), pp. 399-439. 
Figures

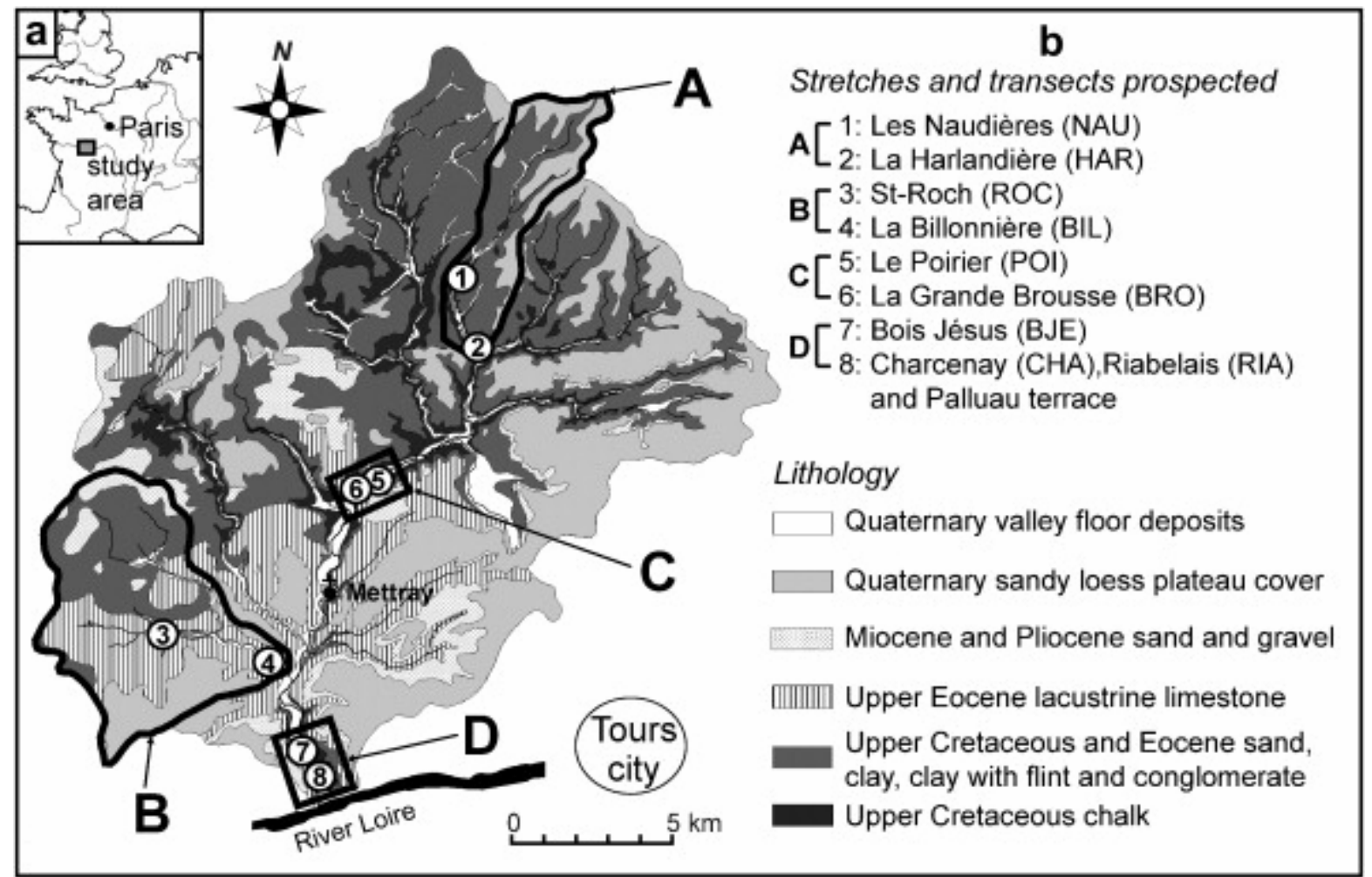

Fig. 1. location maps. a: Location of the studied area in north-western Europe; b: geological map of the Choisille catchment and location of the stretches and transects studied. 


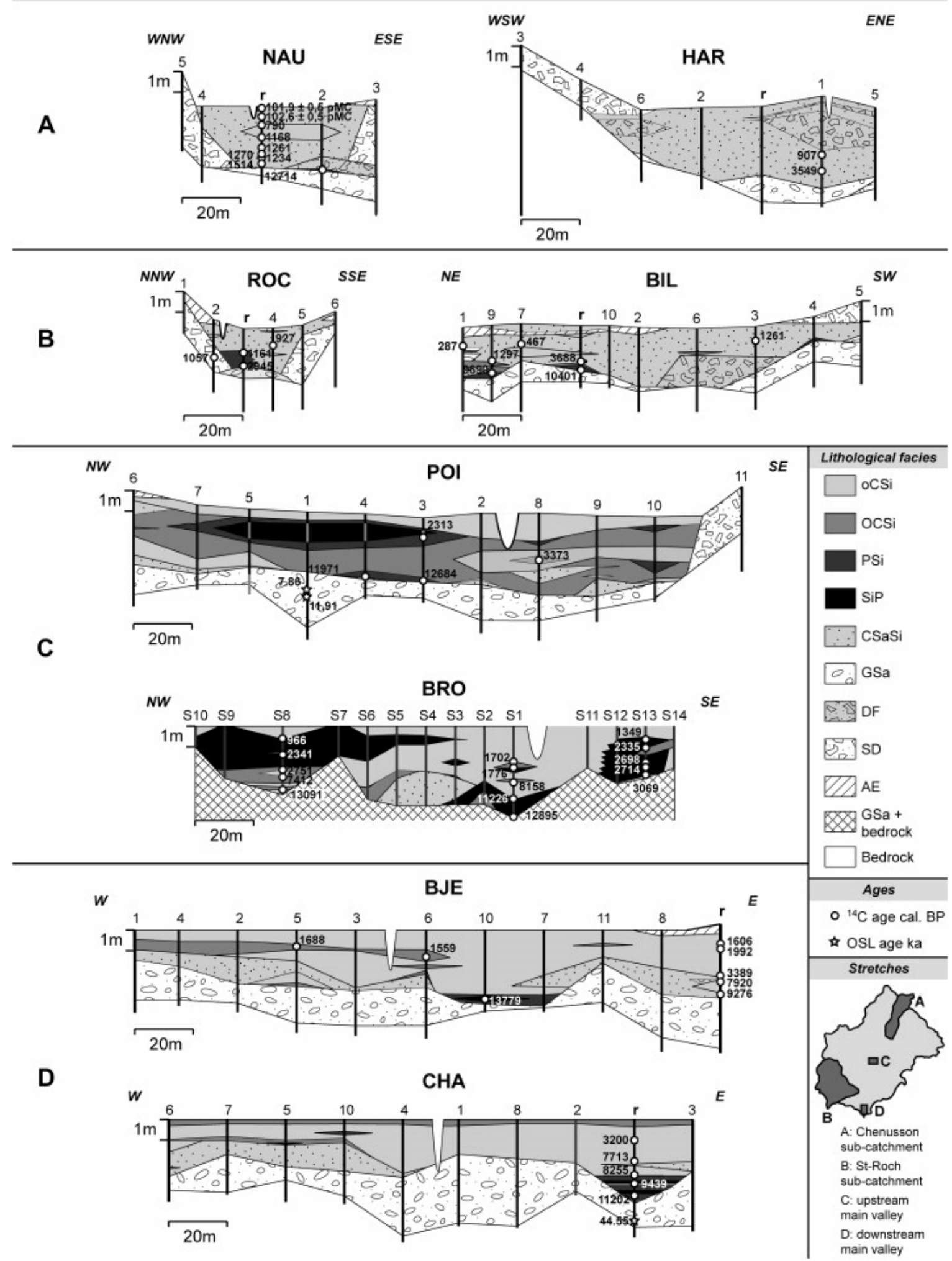

Fig. 2. lithological transects through the floodplain of the Choisille River. The scale is the same for all transects. $1,2 . .$. on the transect: core location. $r$ : reference core. GSa, gravel and sand; PSi, peaty silt; SiP, silty peat; CSaSi, clayey-sandy silt; oCSi, organic-matter poor clayey silt; OCSi, organic-matter rich clayey silt; DF, debris flow; SD, slope deposits; AE, anthropogenic embankment. Ages are reported with the older extreme of $2 \sigma$ calibration range (see the younger extreme in Table 1 ). 


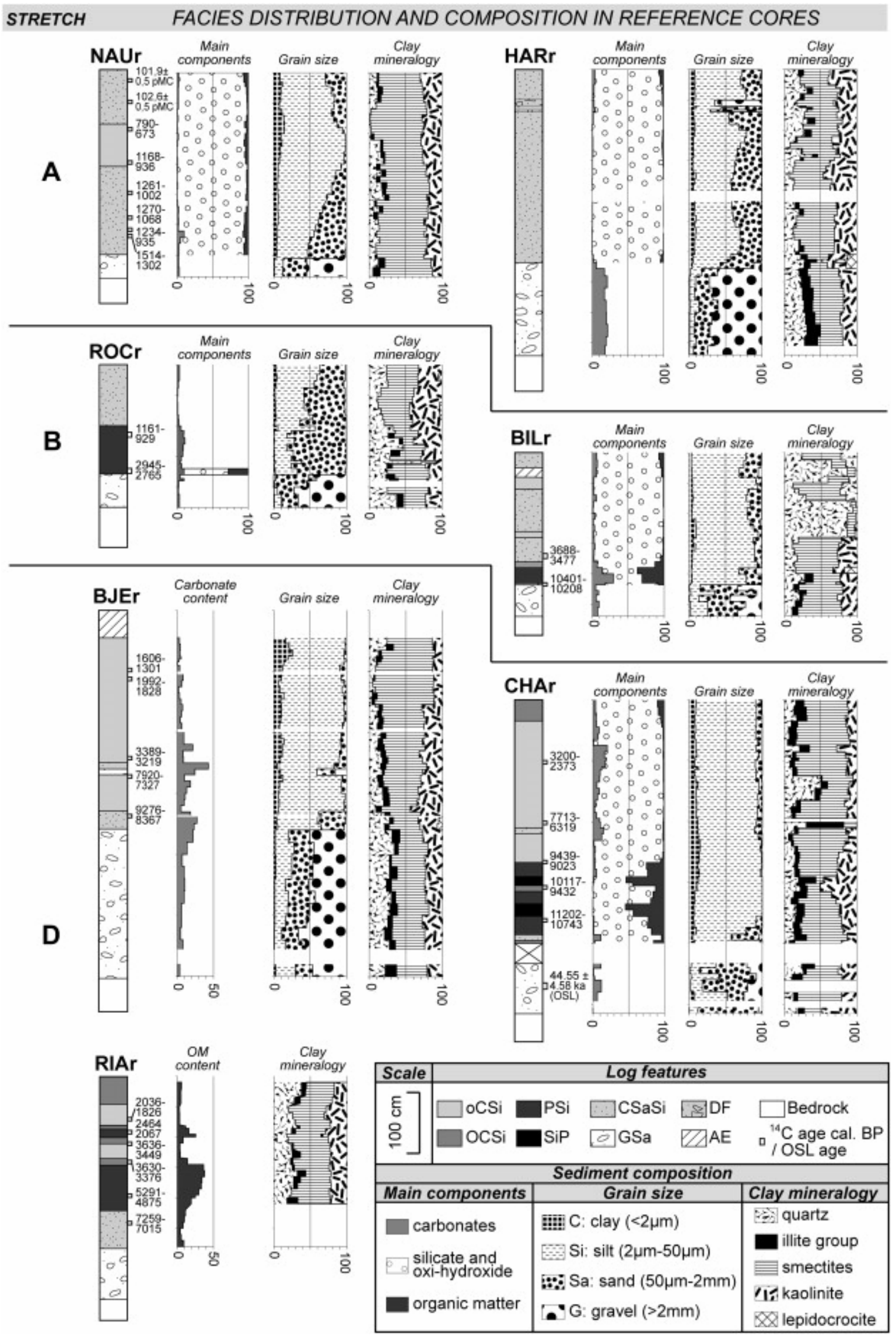

Fig. 3. facies distribution and composition in reference cores. All components are expressed as percentages of the analysed fraction. See Fig. 2 for significance of facies indices. 


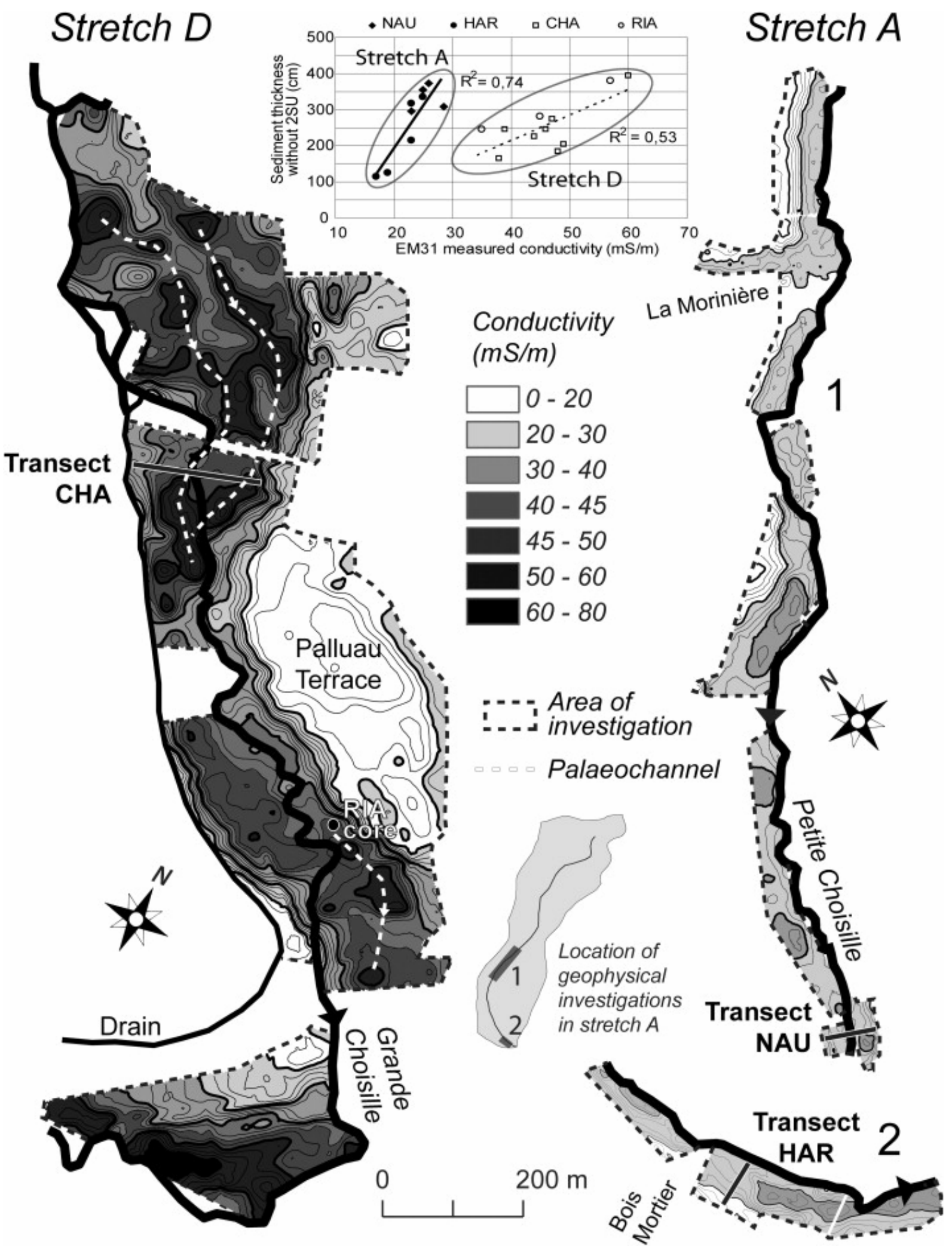

Fig. 4. conductivity maps (EM31) in stretches $A$ and $D$ and comparison between core results (total sediment thickness without $2 \mathrm{SU}$ ) and EM31 values. Isocontour lines are drawn every $2.5 \mathrm{mS} / \mathrm{m}$. Cores located $7 \mathrm{~m}$ apart the actual channel are not considered. 


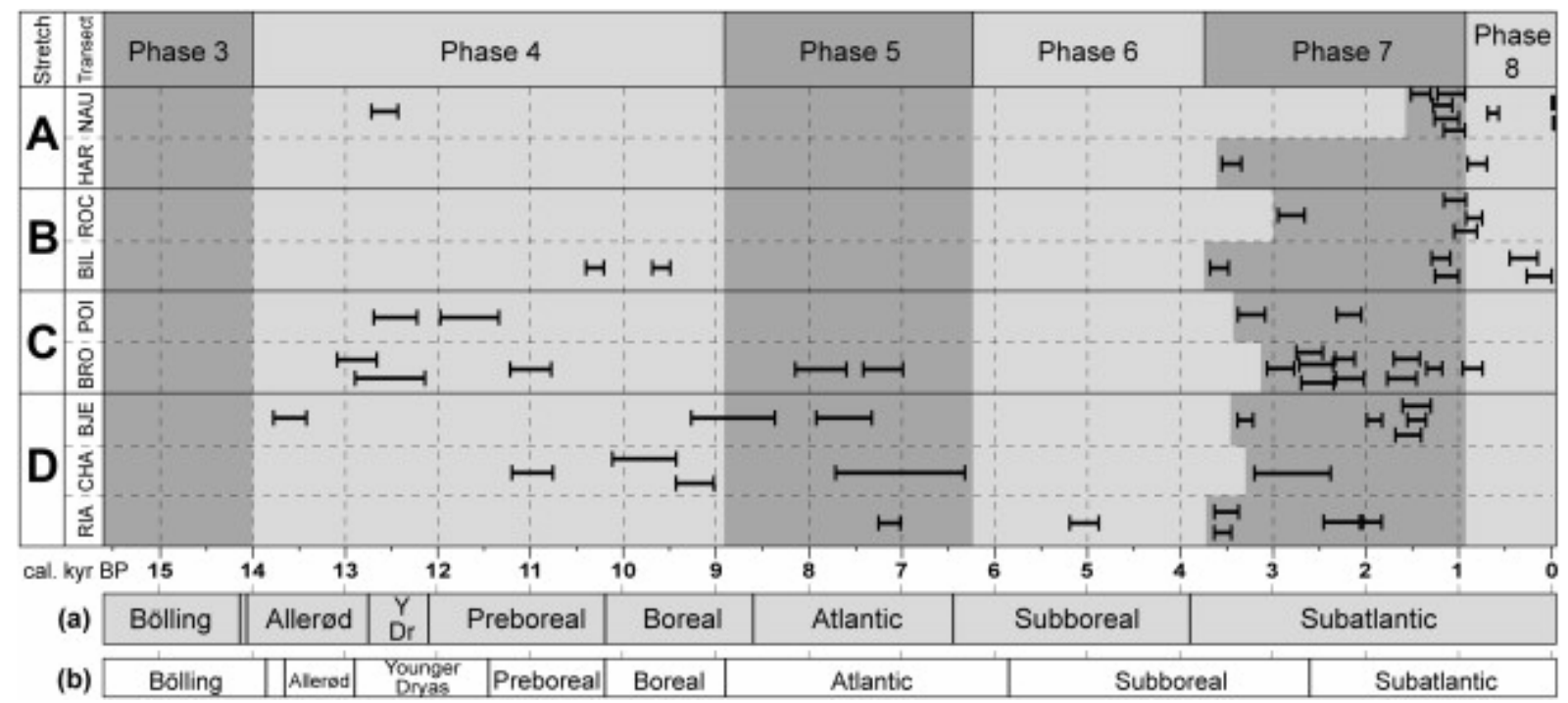

Fig. 5. distribution of ${ }^{14} \mathrm{C}$ cal. ages in the stretches and transects studied and of the main evolutionary phases of the Choisille River during the LateGlacial and Holocene. RIA: only one core. (a): regional chronozone boundaries in median cal. ages BP according to Visset et al. (2005); (b): conventional chronozone boundaries in median cal. ages BP according to Mangerud et al. (1974). 


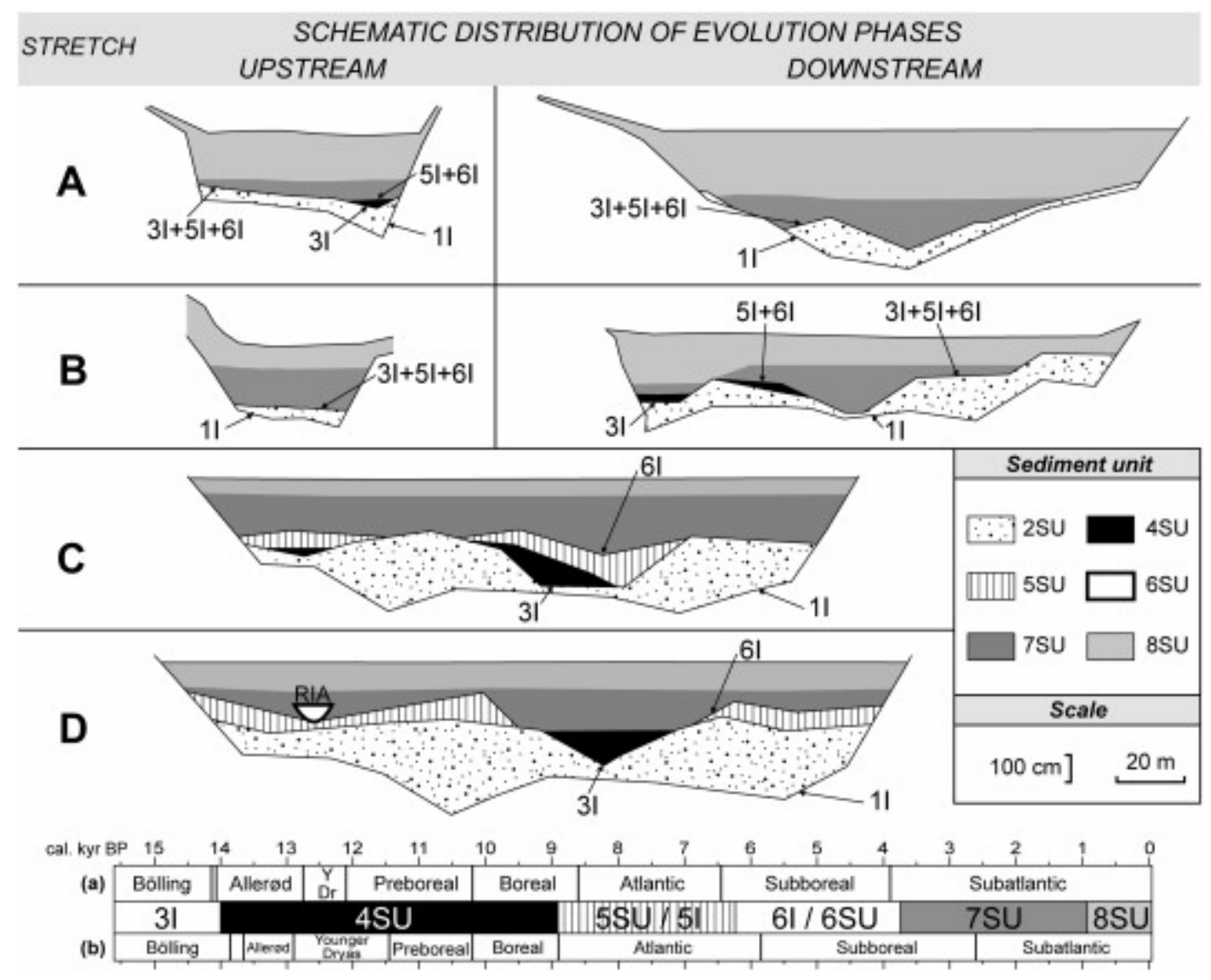

Fig. 6. synthetic transects through the Choisille floodplain showing the distribution of the main evolutionary phases in each of the four stretches studied. 1 to 8: evolution phases; I: incision; SU: deposition of sediment unit. See Fig. 5 for (a) and (b) significance. 


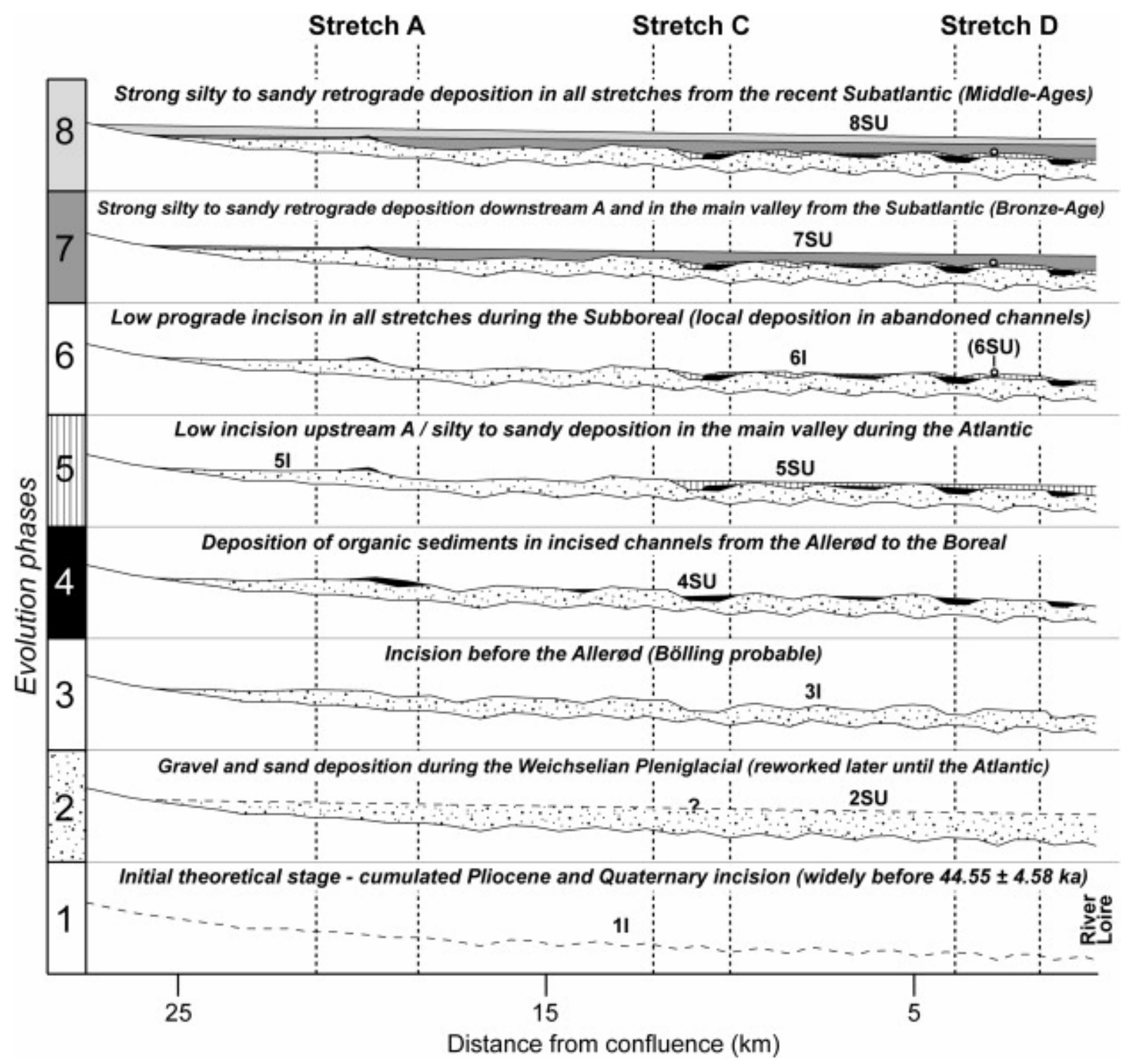

Fig. 7. schematic longitudinal sections through the Choisille floodplain showing its upstream-downstream evolution during each phase.

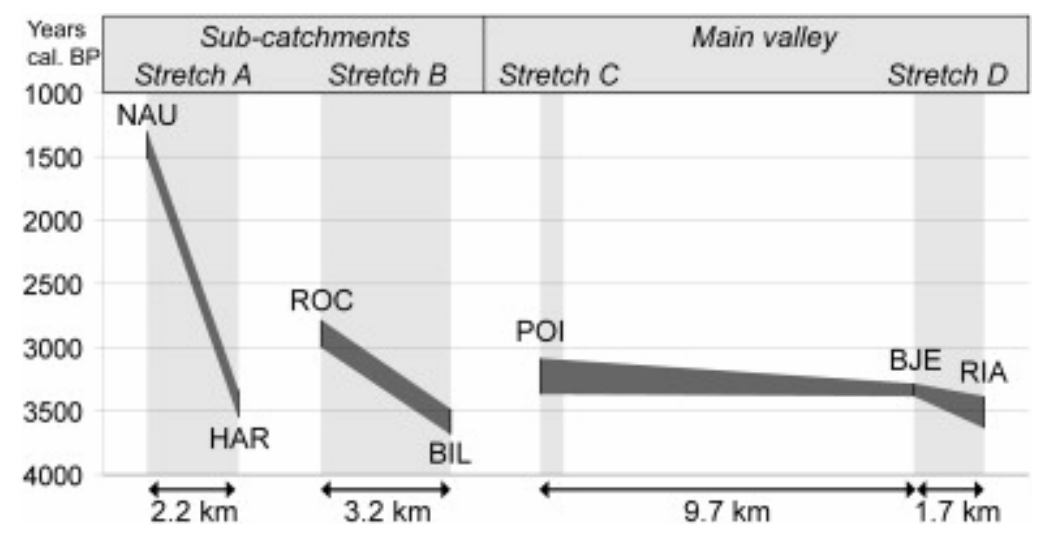

Fig. 8. upstream-downstream non-univocal variation of the age of the 7SU unit bottom in the Choisille floodplain. 
Table $1 .{ }^{14} \mathrm{C}$ dates on the Choisille river sediments.

\begin{tabular}{|c|c|c|c|c|c|c|}
\hline Stretch & Core $^{\mathbf{a}}$ & $\begin{array}{l}\text { Depth } \\
\text { (cm) }\end{array}$ & $\begin{array}{l}\text { Lab. } \\
\text { reference }\end{array}$ & ${ }^{14} \mathrm{C}$ age $\mathrm{BP}$ & $\begin{array}{l}2 \sigma \text { calibrated age } \\
\text { ranges } \mathrm{BP}^{\underline{b}}\end{array}$ & Material \\
\hline \multirow[t]{11}{*}{$\mathrm{A}$} & NAUr & $15-20$ & Beta - 231912 & $\begin{array}{l}101.9 \pm 0.5 \\
\text { pMC }\end{array}$ & & $\begin{array}{l}\text { organic } \\
\text { sediment }\end{array}$ \\
\hline & NAUr & $50-55$ & Beta - 243071 & $\begin{array}{l}102.6 \pm 0.5 \\
\text { pMC }\end{array}$ & & $\begin{array}{l}\text { organic } \\
\text { sediment }\end{array}$ \\
\hline & NAUr & $95-100$ & Beta - 231913 & $810 \pm 40$ & $790-673$ & $\begin{array}{l}\text { organic } \\
\text { sediment }\end{array}$ \\
\hline & NAUr & $150-155$ & Beta - 231914 & $1120 \pm 40$ & $1168-936$ & $\begin{array}{l}\text { organic } \\
\text { sediment }\end{array}$ \\
\hline & NAUr & $200-205$ & Beta - 231915 & $1200 \pm 40$ & 12611002 & $\begin{array}{l}\text { organic } \\
\text { sediment }\end{array}$ \\
\hline & NAUr & $240-245$ & Beta - 231916 & $1240 \pm 40$ & $1270-1068$ & $\begin{array}{l}\text { organic } \\
\text { sediment }\end{array}$ \\
\hline & NAUr & $260-265$ & Beta - 231917 & $1150 \pm 60$ & $1234-935$ & wood \\
\hline & NAUr & $270-275$ & Beta - 231918 & $1490 \pm 40$ & 1514-1302 & $\begin{array}{l}\text { organic } \\
\text { sediment }\end{array}$ \\
\hline & NAU2 & $300-310$ & Beta - 247277 & $10660 \pm 60$ & $12714-12431$ & peat \\
\hline & HAR1 & 285 & Beta - 247275 & $870 \pm 40$ & $907-695$ & peat \\
\hline & HAR1 & $366-370$ & Beta - 247276 & $3190 \pm 40$ & 3549-3341 & peat \\
\hline \multirow[t]{11}{*}{ B } & ROC2 & $175-185$ & Beta -247280 & $1040 \pm 40$ & $1057-804$ & peat \\
\hline & $\mathrm{ROCr}$ & $110-120$ & Beta - 247281 & $1080 \pm 40$ & $1161-929$ & peat \\
\hline & $\mathrm{ROCr}$ & $170-180$ & Beta - 247282 & $2750 \pm 40$ & $2945-2765$ & peat \\
\hline & ROC4 & $80-85$ & Beta - 247283 & $930 \pm 40$ & $927-744$ & $\begin{array}{l}\text { charred } \\
\text { material }\end{array}$ \\
\hline & BIL1 & $80-90$ & Beta - 247268 & $160 \pm 40$ & $287-0$ & peat \\
\hline & BIL3 & $66-70$ & Beta - 247269 & $1200 \pm 40$ & $1261-1002$ & $\begin{array}{l}\text { charred } \\
\text { material }\end{array}$ \\
\hline & BIL 7 & $94-100$ & Beta - 247270 & $290 \pm 40$ & $467-155$ & peat \\
\hline & BILr & $166-177$ & Beta - 247271 & $3350 \pm 40$ & $3688-3477$ & wood \\
\hline & BILr & $215-220$ & Beta - 247273 & $9120 \pm 40$ & $10401-10208$ & peat \\
\hline & BIL9 & $160-175$ & A 15273 & $1290 \pm 40$ & $1297-1093$ & wood \\
\hline & BIL9 & $225-237$ & A 14274 & $8605 \pm 55$ & $9690-9493$ & peat \\
\hline \multirow[t]{2}{*}{$\mathrm{C}$} & POI3 & $95-100$ & A 15270 & $2165 \pm 40$ & $2313-2045$ & peat \\
\hline & POI3 & $288-295$ & A 15275 & $10585 \pm 75$ & $12684-12220$ & peat \\
\hline
\end{tabular}




\begin{tabular}{|c|c|c|c|c|c|c|}
\hline Stretch & Core $^{\mathbf{a}}$ & $\begin{array}{l}\text { Depth } \\
\text { (cm) }\end{array}$ & $\begin{array}{l}\text { Lab. } \\
\text { reference }\end{array}$ & ${ }^{14} \mathrm{C}$ age BP & $\begin{array}{l}2 \sigma \text { calibrated age } \\
\text { ranges } B P^{\underline{b}}\end{array}$ & Material \\
\hline & POI4 & 280-290 & A 15271 & $10080 \pm 65$ & 11971-11340 & peat \\
\hline & POI8 & $225-230$ & A 15272 & $3050 \pm 45$ & $3373-3082$ & wood \\
\hline & BRO1 & $165-170$ & A 12966 & $1670 \pm 50$ & $1702-1417$ & peat \\
\hline & BRO1 & 195-200 & A 12965 & $1710 \pm 50$ & $1776-1449$ & peat \\
\hline & BRO1 & $265-270$ & A 12967 & $7025 \pm 145$ & $8158-7594$ & $\begin{array}{l}\text { organic } \\
\text { sediment }\end{array}$ \\
\hline & BRO1 & $345-250$ & A 12968 & $9680 \pm 65$ & $11226-10784$ & peat \\
\hline & BRO1 & $435-440$ & A 12969 & $10680 \pm 140$ & $12895-12142$ & peat \\
\hline & BRO8 & $55-60$ & A 12970 & $970 \pm 50$ & 966-765 & $\begin{array}{l}\text { organic } \\
\text { sediment }\end{array}$ \\
\hline & BRO8 & 130-135 & A 12971 & $2220 \pm 50$ & $2341-2124$ & peat \\
\hline & BRO8 & 205-210 & A 12972 & $2530 \pm 45$ & $2751-2461$ & peat \\
\hline & BRO8 & $240-245$ & A 12973 & $6270 \pm 70$ & $7412-6987$ & $\begin{array}{l}\text { organic } \\
\text { sediment }\end{array}$ \\
\hline & BRO8 & 300-305 & A 12974 & $10980 \pm 90$ & 13091-12660 & $\begin{array}{l}\text { organic } \\
\text { sediment }\end{array}$ \\
\hline & BRO13 & $60-65$ & A 12975 & $1360 \pm 45$ & $1349-1179$ & peat \\
\hline & BRO13 & $100-105$ & A 12976 & $2180 \pm 55$ & 2335-2014 & peat \\
\hline & BRO13 & $170-175$ & A 12977 & $2415 \pm 35$ & $2698-2348$ & peat \\
\hline & BRO13 & 190-195 & A 12978 & $2470 \pm 45$ & $2714-2363$ & peat \\
\hline & BRO13 & $230-235$ & A 12979 & $2800 \pm 60$ & 3069-2774 & peat \\
\hline \multirow[t]{9}{*}{$\mathrm{D}$} & BJE5 & $75-80$ & A 14041 & $1635 \pm 45$ & $1688-1409$ & wood \\
\hline & BJE6 & 130 & A 14042 & $1575 \pm 50$ & $1559-1353$ & wood \\
\hline & BJE10 & $335-340$ & A 14044 & $11755 \pm 70$ & 13779-13418 & peat \\
\hline & BJEr & 95-100 & A 14015 & $1550^{-80 /+75}$ & $1606-1301$ & $\begin{array}{l}\text { organic } \\
\text { sediment }\end{array}$ \\
\hline & BJEr & 110-115 & A 14334 & $1965 \pm 35$ & $1992-1828$ & wood \\
\hline & BJEr & $240-245$ & A 14335 & $3100 \pm 35$ & $3389-3219$ & wood \\
\hline & BJEr & $270-275$ & A 14017 & $6725 \pm 145$ & $7920-7327$ & $\begin{array}{l}\text { organic } \\
\text { sediment }\end{array}$ \\
\hline & BJEr & $335-340$ & A 14018 & $7895^{+190 /-185}$ & $9276-8367$ & $\begin{array}{l}\text { organic } \\
\text { sediment }\end{array}$ \\
\hline & CHAr & 100-105 & A 14019 & $2700 \pm 125$ & $3200-2373$ & $\begin{array}{l}\text { organic } \\
\text { sediment }\end{array}$ \\
\hline
\end{tabular}




\begin{tabular}{|c|c|c|c|c|c|c|}
\hline Stretch & Core $^{\mathbf{a}}$ & $\begin{array}{l}\text { Depth } \\
\text { (cm) }\end{array}$ & $\begin{array}{l}\text { Lab. } \\
\text { reference }\end{array}$ & ${ }^{14} \mathrm{C}$ age $\mathrm{BP}$ & $\begin{array}{l}2 \sigma \text { calibrated age } \\
\text { ranges } \mathrm{BP}^{\underline{b}}\end{array}$ & Material \\
\hline & CHAr & $200-205$ & A 14020 & $6240 \pm 340$ & $7713-6319$ & $\begin{array}{l}\text { organic } \\
\text { sediment }\end{array}$ \\
\hline & CHAr & $263-270$ & A 14021 & $8255 \pm 85$ & 9439-9023 & peat \\
\hline & CHAr & $305-310$ & A 14023 & $8625 \pm 105$ & 10117-9432 & peat \\
\hline & CHAr & $360-365$ & A 14022 & $9635 \pm 80$ & $11202-10743$ & peat \\
\hline & RIA & 70 & Beta - 231919 & $1980 \pm 40$ & $2036-1826$ & $\begin{array}{l}\text { organic } \\
\text { sediment }\end{array}$ \\
\hline & RIA & 90 & Beta -231920 & $2270 \pm 70$ & $2464-2067$ & peat \\
\hline & RIA & 110 & Beta - 231921 & $3310 \pm 40$ & $3636-3449$ & $\begin{array}{l}\text { organic } \\
\text { sediment }\end{array}$ \\
\hline & RIA & 140 & Beta -231922 & $3260 \pm 60$ & $3630-3376$ & peat \\
\hline & RIA & 195 & Beta - 231923 & $4450 \pm 70$ & $5291-4875$ & peat \\
\hline & RIA & 240 & Beta - 231924 & $6240 \pm 40$ & $7259-7015$ & $\begin{array}{l}\text { organic } \\
\text { sediment }\end{array}$ \\
\hline
\end{tabular}

${ }^{a}$ NAU transect, 1 core number, $r$ reference core.

${ }^{\mathrm{b}}$ calibration using CALIB (version 6.0) (Stuiver and Reimer, 1993) and IntCal09 calibration dataset (Reimer et al., 2009). 